IZA DP No. 6631

Remittances and Well-Being among Rural-to-Urban Migrants in China

\author{
Alpaslan Akay \\ Corrado Giulietti \\ Juan D. Robalino \\ Klaus F. Zimmermann
}

June 2012 


\title{
Remittances and Well-Being among Rural-to-Urban Migrants in China
}

\author{
Alpaslan Akay \\ IZA
}

Corrado Giulietti

IZA

Juan D. Robalino

Cornell University

Klaus F. Zimmermann

IZA and University of Bonn

\section{Discussion Paper No. 6631 \\ June 2012}

IZA

P.O. Box 7240

53072 Bonn

Germany

\author{
Phone: +49-228-3894-0 \\ Fax: +49-228-3894-180 \\ E-mail: iza@iza.org
}

\begin{abstract}
Any opinions expressed here are those of the author(s) and not those of IZA. Research published in this series may include views on policy, but the institute itself takes no institutional policy positions.

The Institute for the Study of Labor (IZA) in Bonn is a local and virtual international research center and a place of communication between science, politics and business. IZA is an independent nonprofit organization supported by Deutsche Post Foundation. The center is associated with the University of Bonn and offers a stimulating research environment through its international network, workshops and conferences, data service, project support, research visits and doctoral program. IZA engages in (i) original and internationally competitive research in all fields of labor economics, (ii) development of policy concepts, and (iii) dissemination of research results and concepts to the interested public.
\end{abstract}

IZA Discussion Papers often represent preliminary work and are circulated to encourage discussion. Citation of such a paper should account for its provisional character. A revised version may be available directly from the author. 


\section{ABSTRACT \\ Remittances and Well-Being among Rural-to-Urban Migrants in China}

The main objective of this paper is to propose a systematic approach to empirically analyse the effect of remittances on the utility of migrants, as proxied by their subjective well-being (SWB). Using data from a new survey on China (RUMiC), we estimate models in which a measure of subjective well- being is regressed on the level of remittances, and we find a sizeable positive correlation. The effect of remittances on well-being varies with the socioeconomic characteristics of migrants, migration experience and the diversity of family arrangements. As a complementary objective, we use SWB measures to elicit the motivations behind remittances and find evidence that both altruistic (such as pure altruism and reciprocity) and contractual motivations (such as co-insurance and investment) are at work among rural-to-urban migrants in China.

JEL Classification: J61, D63, D64, I3

Keywords: migrants, subjective well-being, remittances

Corresponding author:

Corrado Giulietti

IZA

P.O. Box 7240

53072 Bonn

Germany

E-mail: Giulietti@iza.org

\footnotetext{
* The Longitudinal Survey on Rural Urban Migration in China (RUMiC) consists of three parts: the Urban Household Survey, the Rural Household Survey and the Migrant Household Survey. It was initiated by a group of researchers at the Australian National University, the University of Queensland and the Beijing Normal University and was supported by the Institute for the Study of Labor (IZA), which provides the Scientific Use Files. The financial support for RUMiC was obtained from the Australian Research Council, the Australian Agency for International Development (AusAID), the Ford Foundation, IZA and the Chinese Foundation of Social Sciences.
} 


\section{Introduction}

Remittances represent an enormous cash flow worldwide. In many countries with substantial internal mobility, remittances are also abundant at the national level. For instance, estimates for China show that nearly US $\$ 30$ billion were transferred from urban to rural areas in 2005 (Gong et al., 2008). No work has explored whether and how sending money back home affects the well-being of migrants. Given that remittances often constitute a large share of the earned income of migrants, it is expected that migrants' utility is substantially affected. For instance, migrants' welfare may be positively affected by transferring money to the family left behind, as this contributes to improving the welfare of individuals for whom they care. At the same time, however, migrants may experience a loss in welfare because of the reduction in their own disposable income. The principal aim of this paper is to propose a systematic approach to empirically analyse the effect of remittances directly on the utility of migrants, as proxied by their subjective well-being (SWB) - otherwise termed as "happiness" or "life-satisfaction". The key feature of our approach is that it allows the overall impact of remittances on migrants' well-being to be captured, i.e., including both "monetary" and "non monetary" consequences of sending remittances.

Research on SWB has increased substantially in the past few years, resulting in new insights about economic phenomena that are difficult to capture when using a standard neoclassic economic approach (see the recent surveys in Frey and Stutzer, 2002; Ferrer-i-Carbonell and Van Praag, 2003; Dolan et al., 2008). ${ }^{1}$ Our paper contributes to this literature by documenting the existence of an important relationship between remittances and migrants' well-being. To the best of our knowledge, there is no study that provides empirical evidence about such nexus. ${ }^{2}$

In addition to providing a measure of the direct impact of remittances on migrants' utility, our approach allows us to obtain insight about the motivations behind remittances. Under a policy viewpoint, understanding what drives the remittance behaviour is important in order to assess, for instance, whether public redistributive policies crowd-out private transfers (Cox and Fafchamps, 2007). For long time, the literature has been interested in identifying whether remittances are motivated

$1 \quad$ Among the major findings documented are the relatively large disutility from being unemployed (Clark and Oswald, 1994; Winkelmann and Winkelmann, 1998; Clark, 2003); that age and SWB exhibit a U-shaped relationship (Blanchflower and Oswald, 2004); that married people have higher SWB than those unmarried (Clark and Oswald, 2002); and that both absolute and relative income affect SWB (Easterlin, 1995; Clark et al., 2008).

2 The relationship between remittances and well-being has been explored by Borraz et al. (2010) who focus on the welfare consequences of household members left behind in Ecuador. The authors document that while remittances have a positive effect on well-being, but do not compensate for the costs associated with the absence of migrants from the household. Another strand of the literature that is somewhat related to our approach is that on monetary donations and SWB (Dunn et al., 2008; Konow, 2010; Tsai and Dzorgbo, 2012) 
by altruistic reasons or by the existence of implicit contracts (see Rapoport and Docquier, 2006 for a recent overview). In order to elicit the salient motivations, the typical approach adopted in the literature is to exploit the relationship between remittances flows and pre-remittance income of the family left behind. Yet, no consensus has been reached about which motivation dominates, and a number of studies argue that both altruistic and implicit contracts reasons might be at work (see, e.g., Lucas and Stark, 1985; Cox et al., 2004).

Testing the impact of remittances on the well-being of migrants is particularly relevant in the context of China. In recent decades China has experienced a massive migration of workers from rural to urban areas. The most recent estimates from the 2010 census reveal that over 220 million people left their rural residence for over 6 months (NBS China, 2010). Given the presence of restrictions related to household registration regulations (hukou), the spouse and children of many migrants often have to remain in the village. As a consequence, and also due to the low level of social security in rural areas, remittances are vital for sustaining family members left behind. Due to their increasing numbers in urban areas, the welfare of migrants is becoming an important item in the agenda of central and local policy makers in China. ${ }^{3}$ In addition, there are unique aspects of Chinese culture, such as a strong moral obligation to care for parents and elderly, embodied in the Chinese traditional virtue of "xiao" (filial piety). Arguably, this is an important driver of remittances flows in China (Yue and $\mathrm{Ng}, 1999$ ).

Our analysis is based on a novel survey, the Rural to Urban Migration in China (RUMiC), which collects data on migrants in major urban destinations. The methodology consists on estimating models in which a measure of SWB is regressed on the level of remittances. We document the existence of a sizeable positive correlation between remittances and migrants' well-being, which we refer as to the marginal utility of remittances. The relationship between remittances and well-being varies along socio-economic characteristics of migrants and their migration experience. Furthermore, this relationship is found to be a function of diverse family arrangements. The well-being of migrants with strong implicit family responsibilities (e.g., migrants whose spouse or children are left behind) is less affected by sending remittances. On the other hand, a stronger effect is found among those migrants with fewer responsibilities, in other words, migrants whose choice to remit is less constrained (e.g., single migrants with no children). In regards to filial obligations, we

3 According to hukou regulations, migrants are allowed to reside in a city as long as they are employed or up to six months after unemployment. During the 1990s, the hukou regulations were partially reformed. Since then, migrants who attain certain levels of education or income, have been allowed to obtain urban hukou. More recently, migrants have been allowed to have partial access to public medical insurance in urban areas. Yet, the persistence of hukou regulations still implies that welfare is accessible mostly at the place of residence. Hence migrants are not eligible to access benefits such as public housing and pensions schemes. Furthermore, they are often employed in low-wage occupations. 
find that migrants who are more detached from their family back home experience relatively higher well-being when sending remittances to their parents. When exploring the reasons behind remittances, we find support that both altruistic (such as pure altruism and reciprocity) and contractual motivations (such as co-insurance and investment) are at work, albeit our results suggest that altruism is the dominant motivation.

The remaining of the paper is organized as follows. Section 2 describes the dataset and the empirical strategy. Section 3 outlines the results of our benchmark model and robustness checks, followed by the analysis by socio-economic groups, migration experience and family arrangements. In Section 4 we explore the motivations behind remittances. Section 5 provides concluding remarks.

\section{Data and empirical strategy}

\subsection{Data and description of the sample}

The analysis of this paper is based on the Rural Urban Migration in China (RUMiC) dataset. This dataset relies on a survey in China which has been conducted since 2008 and comprises of three components: the Urban Household Survey (UHS), the Rural Household Survey (RHS), and the Migrant Household Survey (MHS). For the purposes of our analysis we principally use data from the first wave of the MHS, although we also extract some information from the first wave of the RHS, both conducted at the beginning of $2008 .^{4}$

The data cover rural-to-urban migrants, randomly sampled from 15 of the major urban destinations in China, and provide an accurate representation of the migrant population, including temporary workers. The MHS is hence highly representative of the mass labor mobility currently taking place in China (see Kong, 2010, for a detailed description and discussion of the methodological aspects of the RUMiC data).

The original sample of the 2008 MHS covers 5,000 migrant households. A migrant is defined as an individual who lived in an urban area in 2007 but is officially registered as a rural resident, i.e., he or she possesses a rural household registration (rural hukou). We restrict our analysis to household heads who are employed and

$4 \quad$ Although there are currently more recent waves of RUMiC, our analysis focuses on the first wave, as this collects information about a period which precedes the financial crisis started at the end of the 2000s. The ability of the survey to track migrants over time in urban areas was hindered by the beginning of the financial crisis. As of the end of 2008, around 23 million migrants had returned to their home village, the majority of them jobless and in need of finding new employment (NBS, 2011). Furthermore, the crisis might have temporarily distorted the remittance behaviour after 2008. Hence in our analysis, we focus on a less recent, but yet more representative, period of time. 
select only cases with complete information. ${ }^{5}$ This yields a final sample of 4,675 household heads. We extract information on socio-demographic and economic characteristics of the migrants as well as their family arrangements. We also gather detailed data about the migration experience of the household head, such as how much money is remitted back home, information about migration history (e.g., years since first migration) and migration intentions (e.g., whether the migrants would like, hypothetically, to continue living in the city).

\subsection{The measure of well-being}

The literature has explored various proxies of SWB which are generally based on "happiness", "life-satisfaction" or "mental health" measures (Frey and Stutzer, 2002). The MHS includes the 12 standard questions of the General Health Questionnaire (GHQ) on mental health, a measure of SWB widely employed in the economics and psychology literature (e.g., Clark and Oswald, 1994, 2002). Each question allows responses with scores from 0 to 3. In order to obtain a measure for SWB, we added the scores of the 12 GHQ questions and obtain a SWB index which ranges from 0 to 36. This index, usually referred as to the GHQ-12, can be used to proxy for the latent experienced individual utility (Ferrer-i-Carbonell and Van Praag, 2003; Kahneman and Sugden, 2005; Clark et al., 2008).

Figure 1 shows the overall distribution of the GHQ-12 index in the sample of migrants. This pattern is in line with the one reported in previous studies using other well-being measures (see Clark and Oswald, 1994 for the UK; Winkelmann and Winkelmann, 1998 for Germany). The distribution of the GHQ-12 index is rather skewed, with only few migrants reporting extreme low levels of well-being.

\section{$2.3 \quad$ Summary statistics}

Table 1 reports summary statistics of selected variables for both the whole sample and for the groups who remit and do not remit money back home (Table A1 in the Appendix contains the statistics of the full set of variables used in the analysis). Women are somewhat under-represented. This is due to the fact that men are more likely to be the household head in our sample. Migrants form a young group (the average age is just above 30) and have lived away from their home village for less than eight years on average. Just more than half of the migrants are married, and

5 The sample of household head migrants is essentially composed by employed individuals $(99.5 \%)$. One important reason for this is that few migrants have access to social assistance or unemployment benefits in urban areas (as they are linked to household registration) and hence if they become unemployed and cannot find another job, they are likely to return back to their village. 
Figure 1: Migrants' SWB distribution

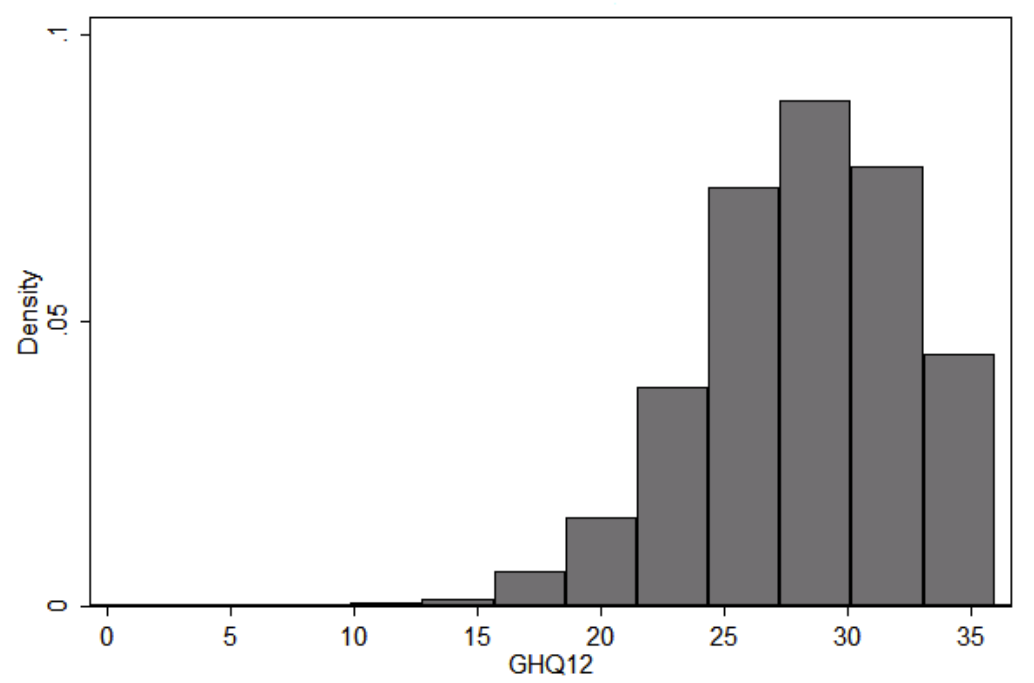

Source: RUMiC 2008.

have on average fewer than one child. ${ }^{6}$ The average number of years of education is below ten, with no major differences between the groups of remitters and nonremitters. Both groups have similar levels of monthly labour income, with an average just below 1,650 Chinese Yuan (CYN).

The table also reports statistics about the SWB and three measures of remittances. A first interesting aspect is that, in terms of raw statistics, there are no appreciable differences in the average level of well-being between remitters and nonremitters. In regards to remittances, nearly $60 \%$ of the migrants send money back home, with an average flow of 200 CYN per month, and 350 CYN per month if only remitters are considered.

Besides the level of remittances, we also consider two alternative measures. The first is per capita remittances. To construct this, we divide the amount of remittances by the number of family members left behind in the village using the weights suggested by the OECD equivalence scale. This measure acknowledges the fact that the impact of remittances and the potential utility that the migrants draw from sending remittances depend on the number of effective recipients. The second alternative measure is the percentage of remittances out of the migrant's household income. This captures a relative measure of remittances, which accounts for the fact that wealthier migrants are expected to remit higher amounts. Our data show that

$6 \quad$ Migrants in our sample originate from both rural areas where the one-child policy, implemented in China since the end of the 1970s, is binding and from areas where the policy is not binding. The fact that migrants report having fewer than one child mainly reflects that they are relatively young and half of them are unmarried. 
remitters send on average $19 \%$ of their income back to their home village.

Table 1: Summary statistics

\begin{tabular}{lcccccc}
\hline \hline & \multicolumn{2}{c}{ All } & \multicolumn{2}{c}{ Remitters } & \multicolumn{2}{c}{ Non-remitters } \\
& mean & s.d. & mean & s.d. & mean & s.d. \\
\hline SWB & 28.47 & $(4.41)$ & 28.53 & $(4.28)$ & 28.39 & $(4.59)$ \\
Age & 30.32 & $(10.07)$ & 30.59 & $(9.68)$ & 29.95 & $(10.58)$ \\
Women (d) & 0.30 & $(0.46)$ & 0.30 & $(0.46)$ & 0.32 & $(0.47)$ \\
Married (d) & 0.53 & $(0.50)$ & 0.57 & $(0.50)$ & 0.48 & $(0.50)$ \\
Number of children & 0.75 & $(0.88)$ & 0.79 & $(0.87)$ & 0.70 & $(0.89)$ \\
Years of education & 9.29 & $(2.39)$ & 9.22 & $(2.41)$ & 9.39 & $(2.37)$ \\
Years since 1 st $^{\text {migration }}$ & 7.74 & $(6.40)$ & 8.18 & $(6.35)$ & 7.13 & $(6.43)$ \\
Labour income (CYN) & 1648.48 & $(1255.72)$ & 1653.36 & $(1155.73)$ & 1641.65 & $(1383.78)$ \\
\hline Sends remittances (d) & 0.58 & $(0.49)$ & 1.00 & $(0.00)$ & & \\
(I) Remittance (CNY) & 202.17 & $(381.96)$ & 346.72 & $(447.33)$ & & \\
(II) Per capita remittances (w.r.t rural family) & 93.66 & $(186.46)$ & 160.63 & $(221.08)$ & & \\
(II) Remittance as \% of household income & 0.11 & $(0.18)$ & 0.19 & $(0.21)$ & & \\
\hline
\end{tabular}

Source: RUMiC 2008. SWB refers to the GHQ-12 index described in the text, and ranges from 0 to 36 . (I) Remittances are constructed using information on the amount of money and commodities remitted back to the home village. (II) Per capita remittances are calculated by dividing the total amount of remittances by the number of members of the migrants' family in the home village using the modified OECD equivalence scale: Per capita remittances $=\frac{\text { Remittances }(1000 C Y N)}{1+0.5 *(\# \text { adults })+0.3 *(\# \text { children })}$. Note we only observe spouse, children, parents and parents in law of migrants. (III) Remittances as a percentage of household income is constructed by dividing the total amount of remittances by the total income of the migrants' household.

\subsection{Empirical strategy}

In this section, we outline the econometric model that we employ in order to estimate the impact of remittances on migrants' well-being. Due to the fact that the SWB index is measured in an ordinal scale, the appropriate model specification is an ordered probit. Yet, our preferred specification throughout the analysis is a linear regression model. Not only the interpretation and comparison of the coefficients are substantially simpler, but estimates from linear regression models and those from ordered probit specifications have been found to be qualitatively similar (Ferrer-iCarbonell and Frijters, 2004). Furthermore, our SWB measure ranges from 0 to 36 and it is hence closer to a continuous measure, which also reinforces the suitability of a linear specification.

The baseline specification is given by the following regression model:

$$
S W B_{i}=\alpha x_{i}+\beta y_{i}+\gamma r_{i}+p_{m}+p_{h}+\epsilon_{i}
$$

where $S W B$ is the subjective well-being of individual $i ; x$ is a vector of sociodemographic characteristics (such as gender, age and marital status) and $\alpha$ is the vector of related parameters to be estimated (a constant term is included as well). The term $y$ represents the household income and $\beta$ captures the marginal utility of income. The key variable is the remittances level $r$. We are therefore interested in the estimate of the parameter $\gamma$, which reveals how SWB varies as a function of the 
remittances - or the marginal utility of remittances. Finally, $p_{m}$ and $p_{h}$ are indicator variables for the provinces where the migrants live and come from, respectively; $\epsilon$ is the error term.

As part of the analysis, we also estimate models in which remittances are interacted with indicators representing selected characteristics of migrants (such as gender, education, years since migration, etc.). The specification that we estimate in these cases builds upon the one above and is given by the following:

$$
S W B_{i}=\alpha x_{i}+\beta y_{i}+\gamma_{1} r_{i} \times D_{i}+\gamma_{2} r_{i} \times\left(1-D_{i}\right)+\eta D_{i}+p_{m}+p_{h}+\epsilon_{i}
$$

where $D$ is the indicator of interest, $\gamma_{1}$ and $\gamma_{2}$ capture the marginal utility of remittances of the pertinent groups $\left(D_{i}=1\right.$ and $D_{i}=0$, respectively) and $\eta$ captures the well-being differential between the two groups conditional on not sending remittances. Throughout the analysis we will report estimates of $\gamma_{1}$ and $\gamma_{2}$, which allows to compare the marginal utility of remittances between the groups of interest.

\section{The effect of remittances on migrants' well-being: empirical results}

The results of our analysis are organised as follows. As a preliminary step, we explore the relationship between remittances and migrants' utility by using standard wellbeing regressions. Our analysis reveals the presence of a strong positive correlation between remittances and well-being. We then conduct tests to demonstrate that our results are not driven by the presence of confounding factors or by the choice of the measure of remittances. Finally, we investigate how the effect of remittances on wellbeing varies in function of the migrants' socio-economic characteristics, migration experience and their family arrangements.

\subsection{Do remittances affect well-being?}

Benchmark estimates We explore the effect of remittances on well-being by first estimating a standard well-being regression model for the migrant population. In practice we estimate two specifications, one with and one without the remittances variable. In Table 2, we report the estimates of the remittances parameter and of a few other key covariates. Table A2 in the Appendix provides full estimation results of our benchmark specification.

Before discussing the impact of remittances, it is useful to outline how the estimates of the regression in our sample compare to those in the existing literature. With a few exceptions, the coefficients of the main socio-economic and demographic characteristics are in line with standard findings from the literature (see Frey and 
Stutzer, 2002; Ferrer-i-Carbonell and Van Praag, 2003; Dolan et al., 2008) for comprehensive reviews on the determinants of SWB). Women report lower levels of wellbeing compared to men, which seems to contrast current findings in the literature. Yet it is important to emphasise that women in our sample are underrepresented. Previous studies have documented the existence of a U-shaped relation between age and happiness (e.g., Blanchflower and Oswald, 2004). Our estimates corroborate the existence of such pattern, yet the coefficients are not estimated with high precision.

Table 2: Benchmark regressions

\begin{tabular}{|c|c|c|}
\hline & I & II \\
\hline Remittances (1000 CNY) & & $\begin{array}{l}0.389 \text { *** } \\
(0,135)\end{array}$ \\
\hline Age & $\begin{array}{l}-0.001 \\
(0.051)\end{array}$ & $\begin{array}{l}-0.001 \\
(0.051)\end{array}$ \\
\hline Age sq. & $\begin{array}{c}0.004 \\
(0.069)\end{array}$ & $\begin{array}{c}0.005 \\
(0,069)\end{array}$ \\
\hline Women (d) & $\begin{array}{l}-0.514 \text { *** } \\
(0.195)\end{array}$ & $\begin{array}{l}-0.506 \text { *** } \\
(0,195)\end{array}$ \\
\hline Married (d) & $\begin{array}{l}0.626 \text { ** } \\
(0.278)\end{array}$ & $\begin{array}{l}0.613 \text { ** } \\
(0,278)\end{array}$ \\
\hline Divorced/widowed (d) & $\begin{array}{l}-1.228^{* *} \\
(0.572)\end{array}$ & $\begin{array}{l}-1.215 \text { ** } \\
(0,572)\end{array}$ \\
\hline Years since $1^{\text {st }}$ migration & $\begin{array}{l}-0.058^{*} \\
(0.034)\end{array}$ & $\begin{array}{l}-0.061 * \\
(0,034)\end{array}$ \\
\hline Years since $1^{\text {st }}$ migration sq. & $\begin{array}{l}0.002 \\
(0.001)\end{array}$ & $\begin{array}{l}0.002 \\
(0,001)\end{array}$ \\
\hline Years of education & $\begin{array}{l}0.165 \text { *** } \\
(0.030)\end{array}$ & $\begin{array}{l}0.165 \text { *** } \\
(0,030)\end{array}$ \\
\hline Labour income (1000 CNY) & $\begin{array}{l}0.140 * * * \\
(0.047)\end{array}$ & $\begin{array}{l}0.115^{* *} \\
(0,047)\end{array}$ \\
\hline Constant & $\begin{array}{l}31.923^{* * *} \\
(2.779)\end{array}$ & $\begin{array}{l}31.979 * * * \\
(2,776)\end{array}$ \\
\hline$R^{2}$ & 0.172 & 0.173 \\
\hline \#Obs. & 4675 & 4675 \\
\hline
\end{tabular}

Source: RUMiC 2008. */**/*** indicate significance at the $10 \% / 5 \% / 1 \%$ level. (d) refers to dummy variables. See Appendix for regression containing full list of covariates.

Being married is associated with higher well-being (similar to what documented by Argyle, 2003 and Helliwell, 2003). The coefficient for the number of years of education is positive and significant (e.g., Fuentes and Rojas, 2001; Helliwell, 2003). Having children does not seem to have a substantial impact on migrants' well-being (some studies have reported a negative impact, see, e.g., Glenn and Weaver, 1978). With regards to the migration experience of the individuals, the time away from 
the home village (as approximated by the years since the first migration) exhibits a convex relationship with SWB. Finally, and consistently with existing evidence, we find a positive association between SWB and income. ${ }^{7}$

When we add remittances to the specification, we find a positive and statistically significant estimate of remittances on SWB. The size of the estimated coefficient is rather large. The estimate of 0.389 implies that a standard deviation increase in the remittance level is associated with a 0.033 increase in the standard deviation of SWB. For comparison, the standardised coefficient for income is 0.032 and that for the dummy for women is 0.052 . The result that the estimate for remittances is as large as - and in some of our models even larger than - the one for income (which is measured in the same unit) seems compatible with a recent study by Dunn et al. (2008), who argue that spending money on other individuals increases well-being more than spending money on oneself. Furthermore, including remittances in the estimation does not substantially influence the estimates of the remaining parameters. For comparison purposes, we have also estimated alternative specifications using an ordered probit model specification. The results are qualitatively similar. ${ }^{8}$

Remittances and SWB: a spurious relationship? The estimates from the benchmark model just outlined reveal the existence of a positive correlation between remittances and migrants' well-being. This suggests that the utility of sending money back home is larger than the disutility associated, for example, with the implied loss of disposable income. This is a striking result. However, it is crucial to ensure that it is not an artifact of some unobservable confounding factors which are not accounted in the regression analysis, or even a consequence of how remittances are defined. In the following, we estimate several specifications to corroborate the robustness of the benchmark results. For the sake of presentation, we will provide the estimates of the remittance parameters only. ${ }^{9}$

As a first test we ensure that our benchmark model is appropriately controlling for the role of income (see Table 3). In other words, we want to make sure that omitted variable bias issues - stemming from the well-known positive correlation between remittances and income - are not substantial. In order to explore this hypothesis, we check the sensitivity of our estimates to the presence of incomerelated variables. In practice, we estimate models which only include remittances

$\overline{7} \quad$ For completeness, we also estimate regression models using the level of remittances as dependent variable. Yet again, the scope is to investigate how our estimates compare to those of previous studies. We consider two specifications (reported in columns 2 and 3 of Table A2 in the Appendix): one for the whole sample of migrants, using tobit regression (which accounts for the censoring of remittances for those migrants who do not send money back home) and one for the sub-sample of remitters. Our results are very similar to previous studies (see, e.g., Lucas and Stark, 1985; Hoddinott, 1994; Vanwey, 2004; Piracha and Saraogi, 2011).

8 The ordered probit models are estimated using a variable which is an aggregation of the GHQ-12 index into a 7-class ordered variable. Estimates are available upon request.

$9 \quad$ Full estimates of all models are available upon request. 
(column I), a model in which we add the years of education (column II), the labour income (column III) and both of them (column IV). Finally, in column V, we show the estimates from a model which further includes the income obtained from other sources (such as from the spouse's wage, from investments or from land or other property). We conduct this sensitivity check for the three alternative definitions of remittances outlined in Table 1 . The rationale is that it is not known a priori how remittances enter the utility function (e.g., in level or in relative terms) and estimates might be sensitive to such measurement.

Table 3: Income, remittances and SWB

\begin{tabular}{|c|c|c|c|c|c|}
\hline & I & II & III & IV & $\mathrm{V}$ \\
\hline Remittances (1000 CNY) & $\begin{array}{l}0.473^{* * *} \\
(0.131)\end{array}$ & $\begin{array}{l}0.452^{* * *} \\
(0.131)\end{array}$ & $\begin{array}{l}0.387^{* * *} \\
(0.134)\end{array}$ & $\begin{array}{l}0.383^{* * *} \\
(0.135)\end{array}$ & $\begin{array}{l}0.389^{* * *} \\
(0.135)\end{array}$ \\
\hline Years of education & & $l^{0.171^{* * *}}$ & & $\begin{array}{l}0.165 * * * \\
(0.030)\end{array}$ & $\left(0.165^{* * *}\right.$ \\
\hline Labour income & & & $\begin{array}{l}0.146 \text { *** } \\
(0.047)\end{array}$ & $\begin{array}{l}0.119^{* * * *} \\
(0.046)\end{array}$ & $\begin{array}{l}0.115^{* *} \\
(0.047)\end{array}$ \\
\hline Other household income & & & & & $\begin{array}{l}0.104^{* *} \\
(0.053)\end{array}$ \\
\hline $\begin{array}{l}\text { Per capita remittances } \\
\text { (w.r.t. rural family) }\end{array}$ & $\begin{array}{l}0.961^{* * *} \\
(0.274)\end{array}$ & $\begin{array}{l}0.898^{* * *} \\
(0.274)\end{array}$ & $\begin{array}{l}0.805^{* * *} \\
(0.275)\end{array}$ & $\begin{array}{l}0.771^{* * *} \\
(0.275)\end{array}$ & $\begin{array}{l}0.7611^{* * *} \\
(0.276)\end{array}$ \\
\hline Years of education & & $\begin{array}{l}0.170^{* * *} \\
(0.030)\end{array}$ & & $\begin{array}{l}0.1644^{* * *} \\
(0.030)\end{array}$ & $\begin{array}{l}0.1644^{* * *} \\
(0.030)\end{array}$ \\
\hline Labour income & & & $\begin{array}{l}0.148^{* * *} \\
(0.046)\end{array}$ & $\begin{array}{l}0.122^{* * *} \\
(0.046)\end{array}$ & $\begin{array}{l}0.119 * * \\
(0.047)\end{array}$ \\
\hline Other household income & & & & & $\begin{array}{l}0.099 * \\
(0.053)\end{array}$ \\
\hline $\begin{array}{l}\text { Remittances as \% } \\
\text { of household income }\end{array}$ & $\begin{array}{l}0.723^{* *} \\
(0.311)\end{array}$ & $\begin{array}{l}0.748^{* *} \\
(0.309)\end{array}$ & $\begin{array}{l}0.717^{* *} \\
(0.310)\end{array}$ & $\begin{array}{l}0.742^{* *} \\
(0.309)\end{array}$ & $\begin{array}{l}0.829^{* * *} \\
(0.311)\end{array}$ \\
\hline Years of education & & $\begin{array}{l}0.173^{* * *} \\
(0.030)\end{array}$ & & $\begin{array}{l}0.1666^{* * *} \\
(0.030)\end{array}$ & $\begin{array}{l}0.166^{* * *} \\
(0.030)\end{array}$ \\
\hline Labour income & & & $\begin{array}{l}0.170 * * * \\
(0.046)\end{array}$ & $\begin{array}{l}0.143 * * * \\
(0.046)\end{array}$ & $\begin{array}{l}0.138 \text { *** } \\
(0.047)\end{array}$ \\
\hline Other household income & & & & & $\begin{array}{l}0.119 * * \\
(0.054)\end{array}$ \\
\hline
\end{tabular}

Source: RUMiC 2008. */**/*** indicate significance at the 10\%/5\%/1\% level. "Other household income" refers to other sources of income such as the spouse's wage, investments, land or other property. All models contain the covariates of the benchmark regression in Table 2.

When we consider the level of remittances, the addition of the years of education and of labour income systematically reduces the size of the estimated coefficient. This suggests that failing to control for income and education would imply an overestimation of the remittances parameter - which absorbs the marginal utility of income. Yet, when adding additional income controls in column $\mathrm{V}$, the estimates of the remittances parameter are remarkably stable. The model in column $\mathrm{V}$ is 
our preferred specification and corresponds to the benchmark estimates of Table 2. When using the per capita remittances variable, the coefficients show a pattern similar to the one just described for the level of remittances. The only apparent exception occurs when we use remittances in percentage of the household income: the estimated coefficient exhibits a rather stable point estimate throughout the various specifications. The likely explanation is that this measure already accounts for the presence of income.

Overall, the specifications in column V show remarkably consistent results: the estimate of the remittance parameter is positive, statistically significant and insensitive to additional income-related variables. ${ }^{10}$ Throughout the analysis, this pattern is substantially similar when per capita remittances or remittances in percentage of income are used. Since the choice of the definition of remittances does not produce appreciable differences in the estimates, in the remaining of the paper we will report only the results for the models which use the level of remittances. ${ }^{11}$

A second set of robustness tests is reported in Table 4. Here we test the sensitivity of the estimates to the presence of unobservable regional attributes. Both the level of SWB and the amount of remittances that migrants send back home are likely to be functions of the characteristics of the region where migrants reside and of the region where they come from. For example, macroeconomic factors - such as the level of prices and the size of the public sector - could vary substantially across regions and thereby affect the estimates. In the first column of Table 4 we estimate a model without province fixed effects; in the second column, we test the importance of the regions of origin by adding dummies for the province where the migrant's hukou is registered; in the third column we investigate the role of the host regions by adding indicators for the province where the migrants reside; finally in the fourth column we introduce indicators for both sending and receiving provinces (this corresponds to our benchmark model in Table 2).

Results suggest that adding regional indicators somewhat reduces the size of the estimated coefficient, which nonetheless remains positive and statistically significant. Furthermore, the estimates appear to be more sensitive to the presence of unobservable factors in the host province. Yet, when adding indicators for both home and host provinces in the last column, the estimated coefficient is rather similar to that in the third column. On the one hand, the results in Table 4 emphasise the importance of controlling for unobservable regional attributes; on the other hand, they suggest that our main results still hold even after controlling for these important confounding factors.

\footnotetext{
$10 \quad$ As described in Table A2 in the Appendix, all models include additional income-related variables, such as an indicator for self-employment status.

11 Detailed results using all three definitions of remittances are available upon request.
} 
Table 4: Sensitivity to unobservable regional characteristics

\begin{tabular}{lclcc}
\hline \hline & No & & Home \& Host \\
& Province Fixed & Home Province & Host Province & Province Fixed \\
& Effects & Fixed Effects & Fixed Effects & Effects \\
\hline Remittances (1000 CNY) & $0.500^{* * *}$ & $0.441^{* * *}$ & $0.376^{* * *}$ & $0.389^{* * *}$ \\
& $(0.135)$ & $(0.136)$ & $(0.132)$ & $(0.135)$ \\
$R^{2}$ & 0.125 & 0.149 & 0.168 & 0.173 \\
\hline
\end{tabular}

Source: $\operatorname{RUMiC} 2008 . * / * * / * * *$ indicate significance at the $10 \% / 5 \% / 1 \%$ level. All models contain the covariates of the benchmark regression in Table 2 .

\subsection{Migrants' heterogeneity}

Socio-demographic and economic characteristics Migrants are quite a diverse population and differ along many characteristics. We explore migrants' heterogeneity by testing the sensitivity of our results to selected socio-demographic and economic characteristics of migrants. In Table 5 we first estimate equation (2) for different groups: men and women, married and unmarried, those below and above the median age (28), below and above the median education level (9 years) and below and above the median income level.

Finally, we also address the presence of unobserved individual heterogeneity. One important concern is that our cross-sectional data do not allow testing for the role of unobserved individual heterogeneity. Yet, the SWB literature has for long discussed that unobserved individual characteristics (such as personality traits or genetic predisposition) are important determinants of SWB (e.g., Diener et al., 1999; Boyce and Wood, 2011). We propose an alternative strategy to - at least partially - control for such latent characteristics. We exclude from the GHQ-12 index the question related to "happiness" (i.e., "How happy are you when you consider each aspect of your life?"), obtaining a "GHQ-11" index. We then use the happiness measure as an additional explanatory variable in the regression. Our argument is that the happiness index can partially account for the unobserved attributes of migrants - at least for those which do not vary over time. ${ }^{12}$

The results in Table 5 show that the estimate for women is larger than for men, albeit the coefficient is estimated with a larger standard error as well, most likely due to the relatively small sample size of this group. Younger migrants exhibit a somewhat larger marginal utility of remittances. This result is particularly interesting in light of the fact that most of the remittances in China consist of transfers from younger individuals to the elderly. Remittances appear to have a stronger effect on single migrants than on married ones, which might reflect differences in the responsibilities inherent to the diverse situations of migrants' families - we will explore

$\overline{12}$ We also estimated models for each group instead of interaction models, obtaining remarkably similar estimates. 
Table 5: Migrants' socio-demographic and economic characteristics

\begin{tabular}{|c|c|c|c|}
\hline Women $(\mathrm{D}=1)$ & $\begin{array}{l}0.506 \\
(0.429) \\
0.373 * * * \\
(0.139)\end{array}$ & $\begin{array}{l}\text { Age } \leq 28(\mathrm{D}=1) \\
\text { Age }>28(\mathrm{D}=0)\end{array}$ & $\begin{array}{c}0.498 \text { ** } \\
(0.215) \\
0.323^{*} \\
(0.165)\end{array}$ \\
\hline Married $(\mathrm{D}=1)$ & $\begin{array}{l}0.343^{* *} \\
(0.148)\end{array}$ & Years of education $\leq 9(D=1)$ & $\begin{array}{l}0.488^{* * *} \\
(0.175)\end{array}$ \\
\hline Single $(D=0)$ & $\begin{array}{l}0.522 * \\
(0.281)\end{array}$ & Years of education $>9(\mathrm{D}=0)$ & $\begin{array}{c}0.223 \\
(0.185)\end{array}$ \\
\hline Labour income $\leq$ median $(D=1)$ & $\begin{array}{l}0.659 * \\
(0.343)\end{array}$ & \multirow{2}{*}{$\begin{array}{l}\text { GHQ-11 model } \\
\text { (Controlling for unobservable } \\
\text { individual characteristics) }\end{array}$} & \multirow[t]{2}{*}{$\begin{array}{l}0.326 \text { ** } \\
(0.127)\end{array}$} \\
\hline Labour income $>$ median $(\mathrm{D}=0)$ & $\begin{array}{l}0.328 * * \\
(0.144)\end{array}$ & & \\
\hline
\end{tabular}

Source: $\mathrm{RUMiC} 2008 . * / * * / * * *$ indicate significance at the $10 \% / 5 \% / 1 \%$ level. All results are obtained by estimating equation (2), except the GHQ-11 model in which the dependent variable is modified by omitting the "happiness" question from the GHQ-12 to obtain the GHQ-11. The index for happiness is used as a regressor (see text for details).

this point in detail in the next subsections. Furthermore, less educated individuals exhibit a somewhat larger effect, a pattern that is also reflected in the group of migrants with an income below the median. ${ }^{13}$ Finally, when considering the GHQ-11 index, the results suggest that the correlation between SWB and remittances is still positive and statistically significant.

Destination, desires and duration of stay The diverse migration experience of the individuals in our sample might as well have an impact on the marginal utility of remittances. We consider this hypothesis by exploring three relevant aspects: the time away from the home village, the distance from home, and future migration intentions. We capture the length of time that the migrant has been away from the home village by using information on when the individual migrated for the first time. We hence construct a variable for the years since migration (YSM). ${ }^{14}$ Then, we derive an indicator for whether the migrants left home for 6 or more years or for less time (this corresponds to the median of the YSM variable). We also estimate an additional specification which uses quartiles of YSM. Similar to the approach used

13 We have also explored the interaction between remittances and income, using quartiles of the income distribution. Even in this case, we found that the marginal utility of remittances decreases monotonically with income. This result reflects the diminishing marginal utility associated with the concavity of the SWB function.

14 It is important to emphasize that since we analyse internal migration, the migration experience could be interrupted, i.e., migrants might have gone back home in between the period that they were interviewed and when they left home for the first time. Yet, an inspection of the RUMiC data suggest that only $16 \%$ of migrants have been back to their hometown for longer than 3 months since their first migration. Hence, circular migration is unlikely to affect our results. 
before, we estimate models interacting the remittance variable with the pertinent YSM indicators.

We acknowledge that proximity of current residence to the home village might have a strong impact on the level of well-being of migrants and on the marginal utility of remittances. We approximate the effect of distance from home by partitioning the sample between migrants who moved within and migrants who moved outside the province of origin (where the hukou is registered). ${ }^{15}$ Our aim is to compare the estimated effect between these two groups. In a similar fashion, we explore the effect of migration intentions by dividing the sample into two groups: migrants who express the wish to continue staying in the host city for an indefinite period and migrants who do not wish to do so. Although this information is only an approximation of the real migration intentions, it provides some insight into how migrants feel about being detached from their home village. ${ }^{16}$

The estimates in the first column suggest that most of the impact of remittances is concentrated on the group of migrants who have lived longer away from home. Similarly, estimates by quartiles of YSM show that the effect of remittances increases. Results in the second column suggest that the effect of remittances is large and statistically significant for those who migrated within the home province, but negligible for those who migrated outside the home province. Interestingly, this result holds over the years since first migration: the effect is negative and large (albeit imprecisely estimated) for the recent migrants who have migrated within the province, and it is positive and statistically significant for migrants who have left their home village for longer time and have moved within the province. Based on these results, we conclude that distance from home reduces the positive impact of remittances on well-being: those who migrate far away from home may feel less attached to the their hometown and the family left behind.

The estimates in column four and five of Table 5 suggest that there is a positive impact of remittances on well-being for both migrants who wish to live indefinitely in the city and migrants who do not wish so. Yet, the latter group of migrants exhibit, on average, an estimate which is much larger than for migrants who wish to live indefinitely in the city (0.573 vs. 0.307). Expressing the desire to live indefinitely in the city might capture a certain detachment of migrants from their hometown or from the family left behind. Hence, they may not feel as satisfied with sending remittances as those who plan to return back home. Consistent with previous results, the marginal utility of remittances increases with the years since migration.

15 RUMiC data indicates that $57 \%$ of migrants moved within the home province.

16 The exact wording of the question is: "If policy allowed, how long would you like to stay in the city?" Hence, this question relates to a hypothetical scenario of a policy allowing unconditional residence of migrants in the city. The hypothetical nature of the question is due to the fact that, in general, policy does not encourage migrants to reside permanently in urban areas. 
Table 6: Duration of stay, destination, and migration intentions

\begin{tabular}{|c|c|c|c|c|c|}
\hline & $\begin{array}{c}\text { Benchmark } \\
\text { model }\end{array}$ & $\begin{array}{l}\text { Migrated } \\
\text { within } \\
\text { province }\end{array}$ & $\begin{array}{l}\text { Migrated } \\
\text { out of } \\
\text { province }\end{array}$ & $\begin{array}{l}\text { Does not } \\
\text { wish to stay } \\
\text { forever }\end{array}$ & $\begin{array}{l}\text { Wishes } \\
\text { to stay } \\
\text { forever }\end{array}$ \\
\hline Remittances (1000 CNY) & $\begin{array}{l}0.389^{* * *} \\
(0.135)\end{array}$ & $\begin{array}{l}0.489^{* *} \\
(0.204)\end{array}$ & $\begin{array}{c}0.184 \\
(0.189) \\
\end{array}$ & $\begin{array}{l}0.573 \text { ** } \\
(0.237)\end{array}$ & $\begin{array}{c}0.307 * \\
(0.166)\end{array}$ \\
\hline $\mathrm{YSM}<6$ & $\begin{array}{l}-0.097 \\
(0.240)\end{array}$ & $\begin{array}{l}-0.376 \\
(0.495)\end{array}$ & $\begin{array}{l}-0.037 \\
(0.266)\end{array}$ & $\begin{array}{c}0.293 \\
(0.412)\end{array}$ & $\begin{array}{l}-0.391 \\
(0.293)\end{array}$ \\
\hline $\mathrm{YSM} \geq 6$ & $\begin{array}{l}0.596 \text { *** } \\
(0.167)\end{array}$ & $\begin{array}{l}0.6822^{* * *} \\
(0.244)\end{array}$ & $\begin{array}{c}0.334 \\
(0.252) \\
\end{array}$ & $\begin{array}{l}0.7111^{* * *} \\
(0.275)\end{array}$ & $\begin{array}{l}0.574 \text { *** } \\
(0.217)\end{array}$ \\
\hline YSM 0-2 & $\begin{array}{l}-0.065 \\
(0.346)\end{array}$ & $\begin{array}{l}-1.425 \\
(0.959)\end{array}$ & $\begin{array}{c}0.389 \\
(0.397)\end{array}$ & $\begin{array}{c}0.505 \\
(0.564)\end{array}$ & $\begin{array}{l}-0.719 \\
(0.471)\end{array}$ \\
\hline YSM 3-5 & $\begin{array}{l}-0.094 \\
(0.329)\end{array}$ & $\begin{array}{c}0.390 \\
(0.521)\end{array}$ & $\begin{array}{l}-0.430 \\
(0.449)\end{array}$ & $\begin{array}{c}0.138 \\
(0.606)\end{array}$ & $\begin{array}{l}-0.149 \\
(0.354)\end{array}$ \\
\hline YSM 6-10 & $\begin{array}{l}0.495 * * \\
(0.242)\end{array}$ & $\begin{array}{c}0.497 \\
(0.341)\end{array}$ & $\begin{array}{c}0.401 \\
(0.367)\end{array}$ & $\begin{array}{c}0.8422^{*} \\
(0.458)\end{array}$ & $\begin{array}{c}0.342 \\
(0.268)\end{array}$ \\
\hline YSM $>10$ & $\begin{array}{l}0.697 \text { *** } \\
(0.212)\end{array}$ & $\begin{array}{l}0.857^{* * *} \\
(0.281)\end{array}$ & $\begin{array}{c}0.254 \\
(0.335) \\
\end{array}$ & $\begin{array}{c}0.6333^{*} \\
(0.340) \\
\end{array}$ & $\begin{array}{l}0.9144^{* * *} \\
(0.293)\end{array}$ \\
\hline \#Obs & 4675 & 2654 & 2021 & 1990 & 2685 \\
\hline
\end{tabular}

Source: $\mathrm{RUMiC} 2008 . * / * * / * * *$ indicate significance at the $10 \% / 5 \% / 1 \%$ level. The results in the second and third panels are obtained by following the interaction model described in equation (2) with the appropriate number of indicators. Each column represents a partition of the sample.

\subsection{Migrants and the family left behind}

Remittances: obligation or choice? Remittances consist mostly of transfers within the household. Therefore, their impact on well-being may be very sensitive to the migrant's family structure and living arrangements, for example, the number of children and elderly, or whether the migrants' family, or part of it, is left behind in the hometown. Some of these aspects represent peculiarities of today's China. For example the "filial piety", i.e., providing care and assistance to parents and elderly members of the family is a very important factor embedded in the Chinese culture (Yue and Ng, 1999). Furthermore, hukou regulations make it difficult for migrants to bring their family to the city, especially young children. As a consequence, the phenomenon of leaving family behind is widespread.

In this section, we examine how our benchmark results are sensitive to the situation of the migrants' close and extended family. We first identify the place of residence of the household-head's spouse, children aged below 16 and parents. We create indicators describing the following family situations: "Single no children", "Migrated with spouse, no children", "Migrated with spouse and children", "Spouse left behind, no children", "Migrated with spouse, all children left behind", and "Spouse and children left behind". This classification allows us to explore whether 
the impact of remittances on SWB follows a particular pattern in function of these diverse family situations. As a preliminary step, Table 7 reports the average remittances for the different groups. As expected, the level of remittances increases with the degree of "responsibilities" towards the family left behind in the hometown. For example, a migrant whose spouse is left behind but has no children remits more than a migrant who is single, but less than a migrant whose spouse and children live in the hometown.

Table 7: Family structure and living arrangements: Summary statistics

\begin{tabular}{lcc}
\hline \hline & Remittance (CNY) & \#Obs \\
\hline Single no children & 153.87 & 2149 \\
Migrated with spouse, no children & $(280.79)$ & \\
& 159.19 & 445 \\
Migrated with spouse and children & $(364.74)$ & \\
& 129.11 & 658 \\
Spouse left behind, no children & $(298.03)$ & \\
& 251.30 & 331 \\
Migrated with spouse, all children left behind & $(374.72)$ & \\
& 303.53 & 432 \\
Spouse and children left behind & $(515.02)$ & \\
& 402.03 & 560 \\
\hline Children and/or spouse left behind & $(578.10)$ & \\
& 320.97 & 1455 \\
No children nor spouse left behind & $(506.02)$ & \\
& 148.49 & 3220 \\
\hline Only parent(s) in home village & $(294.81)$ & \\
\hline Source: RUMiC 2008. & 157.20 & 2473 \\
\end{tabular}

In Table 8 we estimate models in which the remittance variable is interacted with an indicator for each of the migrants' family situations outlined in Table 7. One would expect that migrants with close family members living in the hometown (e.g., the group "Spouse and children left behind") should exhibit a higher marginal utility of remittances. Contrary to this conjecture, we find that the well-being of these groups is not significantly affected by remittances. On the other hand, the largest effect is found among those groups who have fewer family responsibilities (e.g., migrants who are single or who migrate with their spouses but have no children). This result suggests that remittances might be perceived as a strong, implicit obligation by migrants with family responsibilities, making them less satisfied when compared to those migrants who remit but have fewer or no responsibilities. In other words, migrants with fewer responsibilities may experience higher utility because they have a choice whether to remit or not. To further corroborate this result, we reclassify migrants into those with more pronounced family responsibilities (i.e., "Spouse and/or children left behind") and compare them with those migrants with- 
out such responsibilities. Yet again, the estimates confirm that sending remittances is associated with a large effect on SWB only for the latter group, while for those migrants who may feel morally obliged to remit, the coefficient is negligible in size and statistically insignificant.

Table 8: Family structure and living arrangements

\begin{tabular}{|c|c|c|c|c|c|c|c|}
\hline Indicator $(D)$ & $\begin{array}{l}\text { Single, } \\
\text { no } \\
\text { children }\end{array}$ & $\begin{array}{c}\text { Migrated } \\
\text { with spouse, } \\
\text { no } \\
\text { children }\end{array}$ & $\begin{array}{l}\text { Migrated } \\
\text { with } \\
\text { spouse and } \\
\text { children }\end{array}$ & $\begin{array}{l}\text { Spouse left } \\
\text { behind, } \\
\text { no } \\
\text { children }\end{array}$ & $\begin{array}{c}\text { Migrated } \\
\text { with spouse, } \\
\text { all children } \\
\text { left behind }\end{array}$ & $\begin{array}{l}\text { Spouse } \\
\text { and } \\
\text { children } \\
\text { left behind }\end{array}$ & $\begin{array}{l}\text { Children } \\
\text { and/or } \\
\text { spouse } \\
\text { left behind }\end{array}$ \\
\hline$(\mathrm{D}=1)$ & $\begin{array}{l}0.5266^{*} \\
(0.352)\end{array}$ & $\begin{array}{l}1.402^{* * *} \\
(0.333)\end{array}$ & $\begin{array}{c}0.362 \\
(1.506)\end{array}$ & $\begin{array}{c}0.024 \\
(0.436)\end{array}$ & $\begin{array}{l}-0.131 \\
(0.419)\end{array}$ & $\begin{array}{c}0.318 \\
(0.236)\end{array}$ & $\begin{array}{c}0.116 \\
(0.164)\end{array}$ \\
\hline$(\mathrm{D}=0)$ & $\begin{array}{l}0.346^{* *} \\
(0.149)\end{array}$ & $\begin{array}{l}0.284 * * \\
(0.138)\end{array}$ & $\begin{array}{l}0.357^{* *} \\
(0.144)\end{array}$ & $\begin{array}{l}0.404^{* * *} \\
(0.141)\end{array}$ & $\begin{array}{l}0.486 \text { *** } \\
(0.152)\end{array}$ & $\begin{array}{l}0.471 \text { *** } \\
(0.159)\end{array}$ & $\begin{array}{l}0.661 \\
(0.209)\end{array}$ \\
\hline
\end{tabular}

Source: RUMiC 2008. */**/*** indicate significance at the 10\%/5\%/1\% level. Each column is a separate regression. Results are obtained by estimating the interaction model described in equation (2).

Filial piety In order to provide further insight on the importance of the family left behind, we focus on the role of filial obligations. ${ }^{17}$ We use an approach similar to the one in Table 8, and construct an indicator which is equal to one if the migrant has only (either or both) parents in their hometown and zero otherwise. This partition of the data allows us to explore whether our SWB approach is capable of providing insights into the role of filial piety. We explore the results for these two groups in Table 9. In the first column, we report the coefficients of a model in which remittances are interacted with the indicator for whether only parents are left behind. In the remaining columns, we test the sensitivity of the results to both the location of migrants and their migration intentions.

The estimates in the first column suggest that the impact of remittances on SWB is larger for migrants with only parental obligations. Interesting results emerge when we consider the importance of distance and of migration intentions. When we focus on migrants who only have parents in the hometown - different from what we found in Table 6 - migrants exhibit a larger marginal utility of remittances when they migrated outside their home province compared to those who migrated within. Similarly, migrants who wish to stay forever in the city experience higher utility than those who do not. While these results appear to contradict with our estimates for the whole sample in Table 6, they are consistent with the presence of filial obligations. In other words, for those migrants who are more detached from their hometown - because they live faraway from it or because they do not wish to return - remittances have a relatively large impact on SWB, suggesting that they gain utility from helping their parents.

17 More than $75 \%$ of the migrants report having parents still alive in the hometown. This reflects the fact that migrants in our sample are quite young. 
Table 9: Parents and migration experience

\begin{tabular}{lc|cc|cc}
\hline \hline $\begin{array}{l}\text { Only parent(s) } \\
\text { in hometown }\end{array}$ & $\begin{array}{c}\text { All } \\
\text { migrants }\end{array}$ & $\begin{array}{c}\text { Migrated } \\
\text { within } \\
\text { province }\end{array}$ & $\begin{array}{c}\text { Migrated } \\
\text { out of } \\
\text { province }\end{array}$ & $\begin{array}{c}\text { Does not } \\
\text { wish to } \\
\text { stay forever }\end{array}$ & $\begin{array}{c}\text { Wishes to } \\
\text { stay forever }\end{array}$ \\
\hline$(\mathrm{D}=1)$ & $0.589^{* *}$ & 0.353 & $0.723^{* *}$ & 0.461 & $0.678^{* *}$ \\
& $(0.240)$ & $(0.338)$ & $(0.350)$ & $(0.383)$ & $(0.299)$ \\
$(\mathrm{D}=0)$ & $0.297^{*}$ & $0.575^{* *}$ & -0.058 & $0.590 * *$ & 0.140 \\
& $(0.155)$ & $(0.262)$ & $(0.217)$ & $(0.286)$ & $(0.182)$ \\
\hline
\end{tabular}

Source: $\mathrm{RUMiC} 2008 . * / * * / * * *$ indicate significance at the $10 \% / 5 \% / 1 \%$ level. Each column is a separate regression using a partition of the data. Results are obtained by estimating the interaction model described in equation (2).

\section{The motivations behind remittances: altruism or self-interest?}

This section aims at exploring whether our SWB approach can provide insight on the motivations behind remittances. The analysis contained in the previous section suggests that remittances generate utility for migrants. Yet, this result might be driven by several reasons behind sending remittances, such as altruism or selfinterest (Lucas and Stark, 1985). To understand whether our approach is capable of providing information about which motivation dominates in our sample of migrants, we first provide a brief summary of the theoretical and standard empirical approach used to identify these motivations. We then investigate the reasons behind remittances using the standard approach employed in the literature and compare it with the results of our SWB approach.

Theory and empirical approaches There has been a long debate in the literature regarding the motivations behind the sending remittances behaviour. Two major determinants have been proposed: altruism and the presence of implicit contracts between the migrant and the family left behind (sometimes referred to as quid pro quo motivation). The empirical evidence on which motivation dominates is rather mixed, and suggests that both altruistic and contractual motives are at work (e.g., Becker, 1974; Stark and Levhari, 1982; Lucas and Stark, 1985; Secondi, 1997; Gubert, 2002; Cox et al., 2004; Vanwey, 2004; Brown and Jimenez, 2011).

The most common approach to identify the reasons behind the sending remittances behaviour is to analyse the relationship between remittances and the income of the family back home (before remittances). In "pure" altruistic models, it is assumed that the only objective of the migrant is to support individuals left behind. Therefore, the poorer the family back home, the more the migrants would like to remit. Hence, this approach predicts that the remittances level increases as the 
income of the family back home decreases (Becker, 1974; Lucas and Stark, 1985). ${ }^{18}$ On the other hand, under the contractual hypothesis, the migrant remits money in order to comply with an implicit contract with the family back home. In practice, remittances are the price that the migrants pay in exchange of certain contractual services such as co-insurance, inheritance, future investments, children's care, or the "right" to return back home. The price of these services is an increasing function of the wealth level of individuals left behind; thus contractual models predict that remittances increase as the income of the family back home increases (Kotlikoff and Spivak, 1981; Lucas and Stark, 1985; Kimball, 1988; Coate and Ravallion, 1993).

There is still no consensus in the literature about which motivation is dominant, and the empirical evidence is quite mixed (Lucas and Stark, 1985; Secondi, 1997; Agarwal and Horowitz, 2002; Vanwey, 2004). Such mixed evidence inspired the "mixed motives model" developed by Cox et al. (2004). The rationale is that altruism is typical of those households who have an income below a certain subsistence threshold, while the contractual motivation is likely to be at work among those households whose income is above a certain threshold (Agarwal and Horowitz, 2002; Amuedo-Dorantes and Pozo, 2006; Cox and Fafchamps, 2007; Brown and Jimenez, 2011). More recently, studies have explored this research question in the context of China. The main result of these studies suggest that the motivation behind remittances in China is mixed, since altruism alone is not capable of explaining their remittance behaviour (e.g., Secondi, 1997; Ma, 2001; Bai and He, 2002; Murphy, 2002; Feng and Heerink, 2008; Snyder and Chern, 2008).

SWB and motivations behind remittances As a preliminarily check to identify which motivation dominates in our sample, we investigate - as in the standard approach - the relationship between the income (before remittances) of the family left behind and the level of remittances. One of the obstacles for rigorously testing this hypothesis is that our data do not provide a direct measure for the income of the individuals left behind. With this caveat in mind, we use proxy variables which provide insights about the income level of the family left behind. Our preferred proxy is obtained by a question where migrants are asked to provide an estimate of the average unskilled daily wage in their rural home village. ${ }^{19}$

We then estimate a tobit regression of remittances on a full set of covariates (in line with the specification in Table A1 in the Appendix) and including also indicators for each quartile of the distribution of our proxy variable for the income of the rural household. In Figure 2 we report the coefficients which pertain to the

\footnotetext{
18 Becker (1974) model of altruistic remittances assumes "pure" altruism. However, there are other forms of altruism which have been identified in the literature. One example is the "warm glow" altruism suggested by Andreoni (1989).

19 Another key variable that would have been useful for the analysis is the actual level of SWB of the family members left behind. Unfortunately this is not available in our data.
} 
income quartiles of the family left behind. These coefficients are measured in the left y-axis (the third quartile is set as the reference group). Following Cox et al. (2004) and Brown and Jimenez (2011), the simple relationship between remittances and the income of the family left behind can be used as an intuitive way to identify between altruistic and contractual motivations. Our graph reveals the presence of a U-shaped pattern between remittances and the proxy for the income of the family left behind. This suggests that migrants remit more when the family back home is poor (implying the existence of altruistic motivations), but also when family back home is rich (implying the existence of contractual obligations). When the average income of the left behind family is close to the median, the level of remittances is the lowest.

The preliminary results above confirm previous empirical findings of studies on China, i.e., that both motivations are at work (Secondi, 1997; Snyder and Chern, 2008). These results encourage us to explore whether such motivations transpire also when our SWB approach is used. For this, we estimate a regression model using SWB as dependent variable, and interacting the level of remittances with the indicators for the income quartiles. We also report the results in Figure 2, where the coefficients for the interaction variables are measured in the right $y$-axis. The pattern of estimates of the SWB regression is strikingly similar to the one discussed above, i.e., the effect of remittances on well-being is stronger at both high and low levels of the income of the family left behind. These results suggest that well-being is higher both among those migrants who support family members in need and among those who are paying for the price of certain implicit contractual arrangements. In Figure 3, we replicate this analysis by using per capita remittances: the pattern of the two curves is even more similar than the one presented in Figure 2. Another important aspect that emerges is that the turning point of the curves in the graphs is located in correspondence of the third quartile of the income distribution. This leads us to conclude that in our sample, the altruistic motivation dominates the contractual motivation.

We further investigate the effectiveness of our approach to capture the motivation behind remittances by exploring the patterns of the results when information about the income of migrants is added. In Table 10, we estimate a SWB model in line with those used to construct the graphs, with the only difference - for sake of simplicity - that we have an indicator for the median income (instead of quartiles) of the family back home. In the first column, we present the estimates for all migrants; in the remaining two columns, we partition the sample into migrants whose income is above and below the median. The rationale is to investigate how the pattern of our estimates changes in relation to the finding presented in Table 5. The coefficients in column 1 confirm the visual pattern of the graphs: both altruism and contractual obligations are at work. Yet, the former motivation seems to prevail, 
Figure 2: Level of remittances, SWB and income of the family left behind

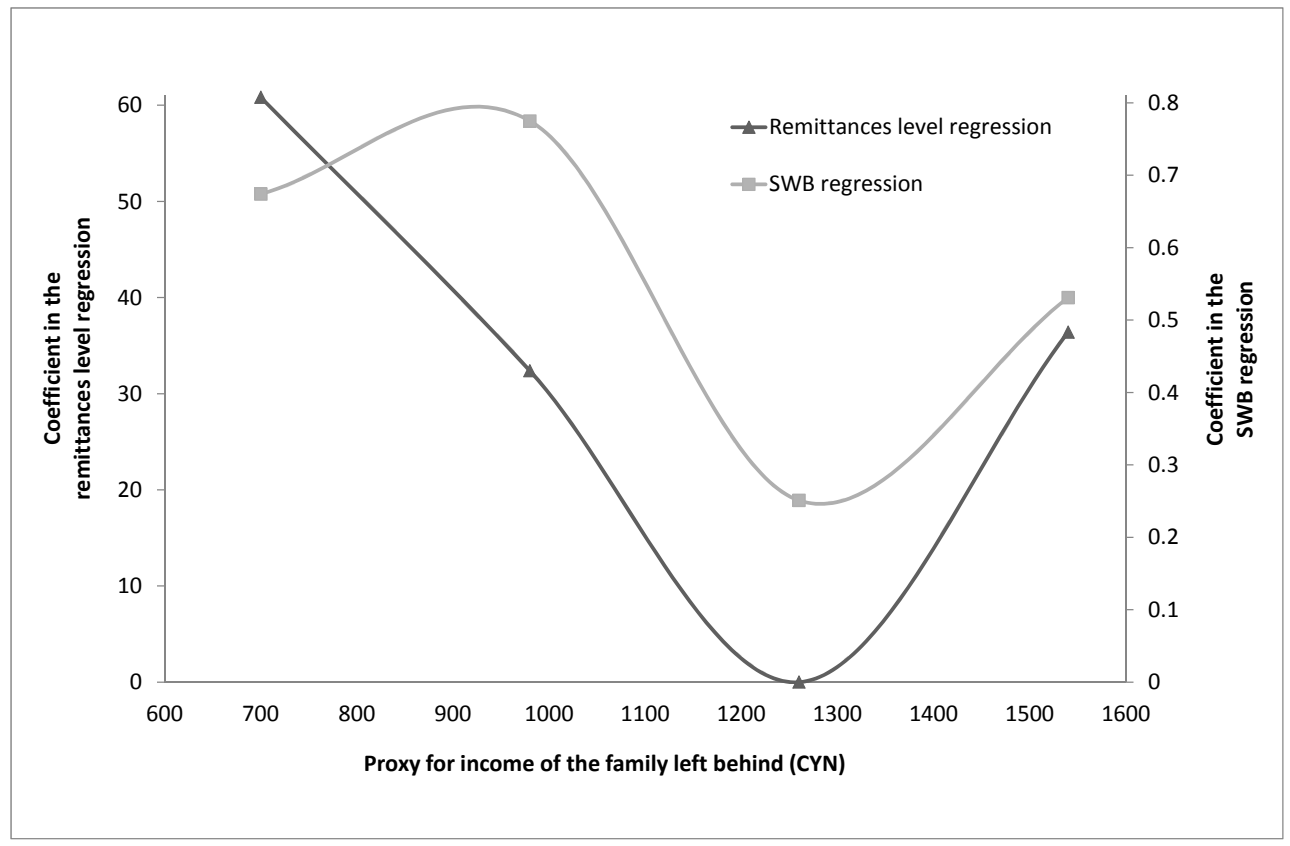

Figure 3: Per capita remittances, SWB and income of the family left behind

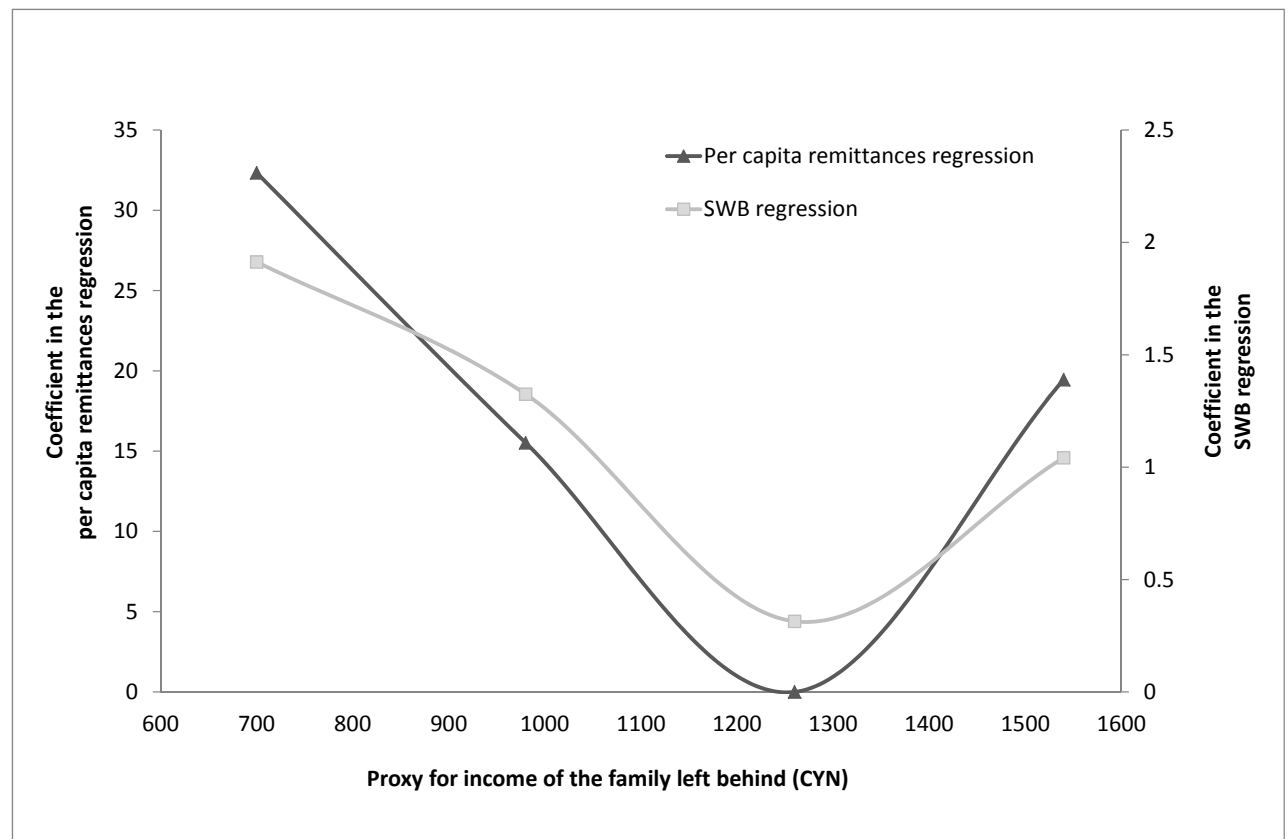

Source: RUMiC 2008. Points from the remittances regression show the marginal remittances level increase with respect to income quartiles of the family left behind (with the $3^{\text {rd }}$ quartile as reference group). Points from the SWB regression capture the marginal utility of remittances for the given income quartile of the family left behind, obtained by estimating the interaction model described in equation (2) with four income indicators. 
as documented by the larger coefficient. The results from the last two columns suggest that poorer migrants (those who were found to have a larger effect in Table 5) sending remittances to richer families are better off than poorer migrants sending remittances to poorer families. This suggests the presence of strong contractual motivations for this group. On the other hand, richer migrants exhibit the opposite pattern suggesting altruistic motivations. ${ }^{20}$

Table 10: Motivation behind remittances

\begin{tabular}{|c|c|c|c|}
\hline Rural family's income & $\begin{array}{c}\text { All } \\
\text { migrants }\end{array}$ & $\begin{array}{c}\text { Below } \\
\text { median }\end{array}$ & $\begin{array}{c}\text { Above } \\
\text { median }\end{array}$ \\
\hline $\begin{array}{l}\text { Above median }(D=1) \\
\text { Bellow median }(D=0)\end{array}$ & $\begin{array}{c}0.338 \text { ** } \\
(0.152) \\
0.629 * * \\
(0.260)\end{array}$ & $\begin{array}{c}0.907 * \\
(0.505) \\
0.373 \\
(0.505)\end{array}$ & $\begin{array}{c}0.259 \\
(0.161) \\
0.693 \text { ** } \\
(0.318)\end{array}$ \\
\hline \# Obs. & 4522 & 2284 & 2238 \\
\hline
\end{tabular}

Source: $\mathrm{RUMiC} 2008 . * / * * * * *$ indicate significance at the $10 \% / 5 \% / 1 \%$ level. Each column is a separate regression using a partition of the data. Results are obtained by estimating the interaction model described in equation (2).

In light of the interesting results in the previous table, we explore the motivations behind sending remittances for some of the key findings in the previous section. This entails that we add one more dimension to the previous analysis. In Table 11, we investigate the patterns along several characteristics of the migrants, such as gender, migration experience and family responsibilities. Each estimate corresponds to the three-way interaction term between remittances, the migrants' income indicator and the indicator for each of the aforementioned characteristics. In line with Table 10, we report estimates for all migrants and then separately for rich and poor migrants.

Migrants' characteristics and motivations One important question in the literature on remittances is to understand whether motivations behind remittances vary by gender (Vanwey, 2004). The results in the top left panel of Table 11 suggest that women who remit to richer families are better off, while those who remit to poorer families exhibit a negative, albeit statistically insignificant, estimate. On the contrary, men who remit to poorer families exhibit higher well-being.

20 We also use two alternative measures to proxy the income of the individuals left behind. One is derived from a question on the economic background of migrants' parents as reported by the respondent (extremely poor, moderately poor, moderately rich and rich). The second is derived by matching through a propensity-score approach the main socio-economic characteristics of the sample of migrants in the Migrant Household Survey with the same characteristics of the sample of migrants who are part of the Rural Household Survey. Information on current migrants in the RHS is obtained by relying on the data provided by the respondents who are present during the interview (in general the household head or spouse). These measures produce similar results to those in Table 10. 
The analysis by years since migration reveals that migrants who have recently left home appear to experience disutility by sending money back home, especially the group of poorer migrants who remit money to poorer families. On the other hand, for those migrants who have migrated for longer time, the impact of remittances is relatively large irrespectively of the economic situation of the family left behind. When we consider migrants who are more attached to their hometown, we find that the altruistic motivation is particularly strong.

As an illustration of strong familial responsibility, we explore the results for the group of migrants whose children are left behind. The magnitude of the coefficients for this group reveals an altruistic pattern. ${ }^{21}$ This can be confirmed by observing that for those migrants without obligations, the pattern of the estimates is similar to the one in Table 10, but with a stronger effect. The final factor that we explore is related to the presence of filial piety. Estimates in the last panel of Table 11 reveal a relatively large effect for those migrants who have only parents left behind in the village, suggesting that filial piety might be behind these strong altruistic motivations. Yet again, for the group of poorer migrants, self-interest motivations are prominent.

Table 12 reports the results using various other attributes which might influence the motivations behind remittances. The variables that we consider allow us to provide insights about more specific reasons why migrants send money back home. For example, in the top left part of the table, we explore the significance of the reasons of migration. This is done by deriving two indicators from the question "Why did you leave your rural hometown?". The first is obtained from those migrants who replied "Too poor at home, want to assist with family expenditure" and the second from those who answered "No future in hometown, didn't like rural life style". In line with the previous analyses, we estimate a model in which we interact each indicator with the level of remittances. Our expectation is that the estimates for the migrants who moved to assist the family economically should follow an altruistic pattern. On the other hand, the results for those individuals who are dissatisfied with life in rural areas should be more consistent with self-interest motivations. The pattern of the estimates corroborates our expectations.

Another set of results in the table explores the role of the help that parents provide to the migrant during the past 12 months. Migrants who report having received financial or psychological support or assistance with daily affairs report a stronger marginal utility of remittances. This pattern is consistent with the presence of reciprocity as motivation to remit. This is corroborated by the finding that those migrants who did not receive help from their parents report a disutility from sending remittances. However, the coefficient is not statistically significant at the

21 In the previous section, we showed that for those migrants with stronger responsibilities, the impact of remittances is negligible and statistically insignificant. 


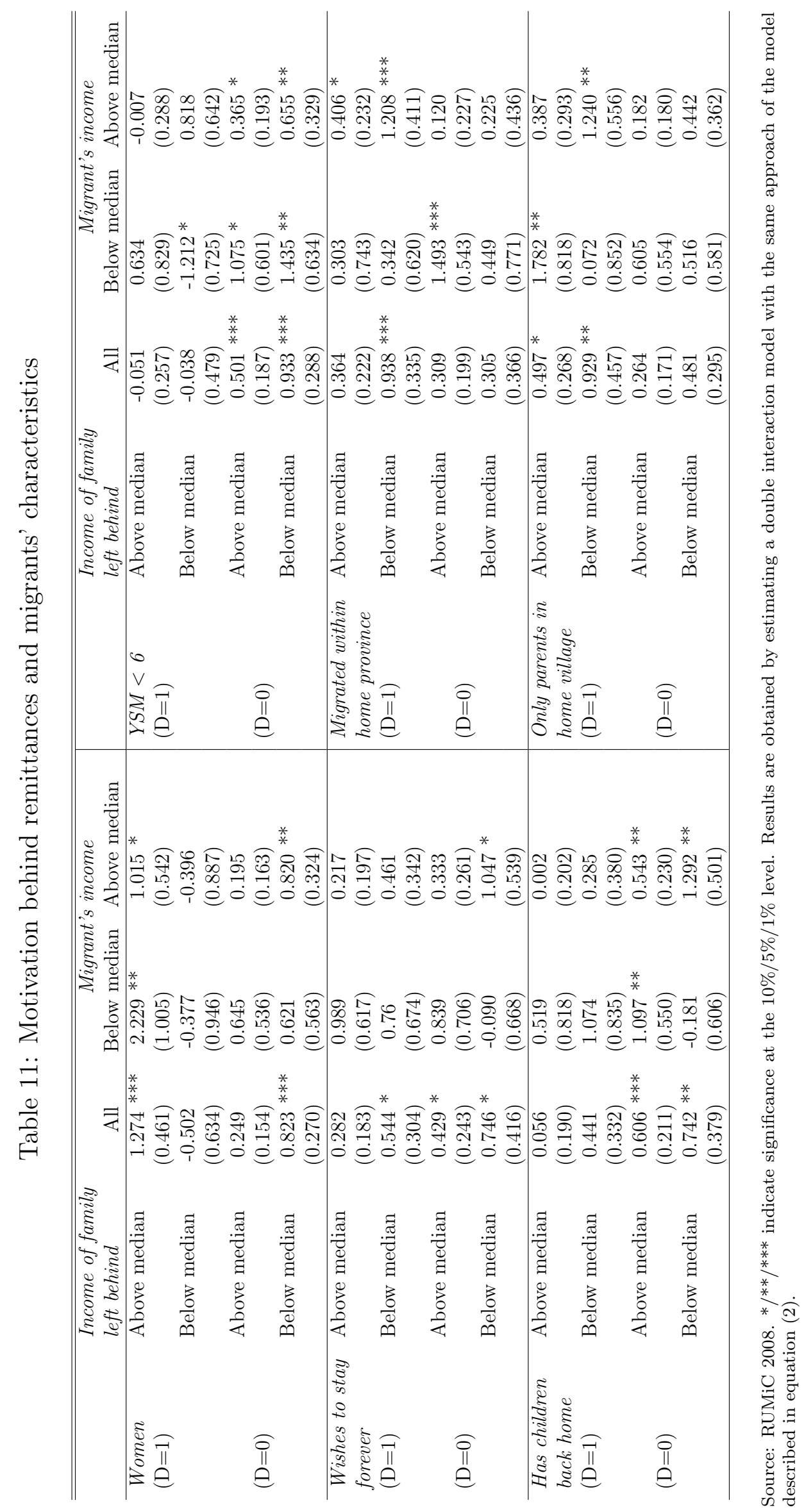




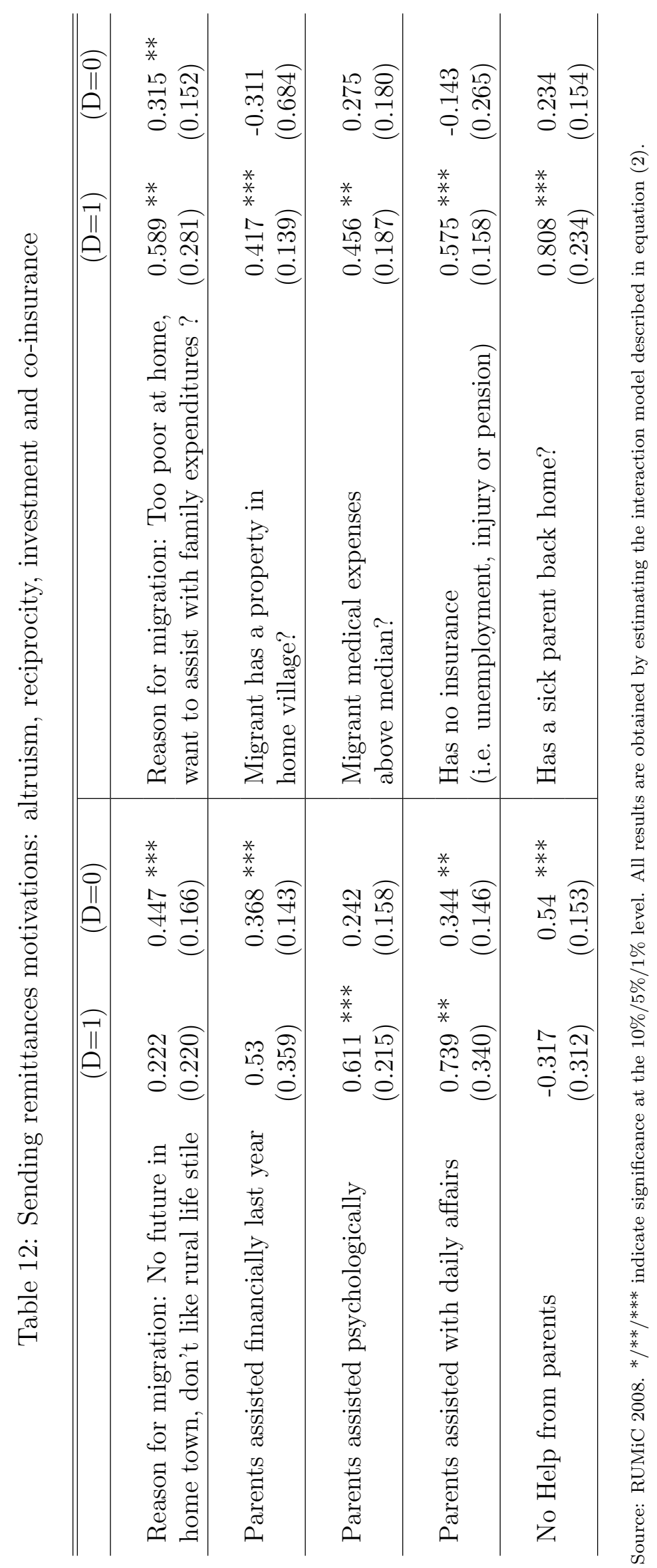


conventional levels.

The effect of remittances on well-being is also higher for those migrants who report having a property in the home village. One potential interpretation is that investment motivations are behind the remittances: the migrant is better off sending money, as this is likely to be used to look after his or her property.

Co-insurance motivations transpire when we analyse individuals with above median health expenditure. Individuals who spend relatively more on health - arguably the less healthy, at least in the context of rural China - report a higher marginal utility of remittances. This might reflect the fact that sending remittances is perceived by these migrants as a form of co-insurance, in that they expect the members of the family left behind to take care of them upon return. ${ }^{22}$ This result is confirmed when focusing on migrants who report not having any form of insurance (i.e., pension, employment or health). Since these individuals need to be hedged against various risks (e.g., loosing a job), sending remittances is associated with higher well-being since the family back home is perceived as a safety net in case of adverse events.

Finally, our results indicate that when migrants have a sick parent back at home they are happy to assist the family, at least financially. This result is compatible with altruism being the motivation behind sending money back home.

\section{Summary and conclusion}

This paper has two objectives. First, we examine the impact of remittances on the subjective well-being of migrants in China. Second, we document that subjective well-being data can be used to obtain new insights about the motivations underlying the behavior of sending remittances. Our methodology is based on estimating wellbeing regression models using remittances as one of the regressors. Our results indicate that migrants experience welfare gains by sending remittances. This result is robust to model specifications and the presence of individual and regional unobserved heterogeneity. Furthermore, we investigate the role of migration experience. We find that the impact of remittances is significant only for those migrants who moved within the province and for those who would like to eventually return back home, aspects which capture both physical and psychological proximity to the family left behind.

Significant differences emerge when we examine the role of family arrangements. Our estimates suggest that migrants with family responsibilities are not as satisfied by sending remittances as those without such obligations. This suggests that implicit obligations to remit mitigate the positive effect of remittance on well-being. We also find evidence that filial obligations appear stronger among those who are more detached from their families left behind.

22 A very similar pattern emerges when we use indicators for health status. 
In order to explore the motivations behind the remittance behaviour we study the relationship between subjective well-being and remittances as a function of the income of family left behind. We find evidence that both altruistic and contractual motivations are at work in our sample, albeit our estimates suggest that the former motivation is the dominant one. In addition, our method allows us to explore how these motivations vary as a function of the migration experience and the family obligations.

To the best of our knowledge, this study is the first attempt to use self-reported well-being to estimate the impact of remittances on migrants' utility and to elicit their motivations to remit. Understanding the welfare impact of remittances is of great importance especially in countries such as China, where the magnitude of internal migration has reached phenomenal proportions. Our findings may have several policy implications. First, the well-being of migrants can be enhanced by facilitating remittances. Second, the finding that money transfers are not entirely motivated by altruistic reasons implies - in line with evidence from previous research - that private transfers might not be crowded-out by public transfers. 


\section{References}

Agarwal, R. and A. Horowitz (2002). Are international remittances altruism or insurance? Evidence from Guyana using multiple-migrant households. World Development 30(11), 2033-2044.

Amuedo-Dorantes, C. and S. Pozo (2006). Migration, remittances, and male and female employment patterns. The American Economic Review 96(2), 222-226.

Andreoni, J. (1989). Giving with impure altruism: Applications to charity and ricardian equivalence. The Journal of Political Economy 97(6), 1447-1458.

Argyle, M. (2003). Well-Being: The Foundations of Hedonic Psychology - Chapter 18: Causes and Correlates of Happiness. Russell Sage Foundation Publications.

Bai, N. and Y. He (2002). Return or migrate? The study of return migration in Anhui and Sichuan. Shehuixue Yanjiu [The Study of Sociology] 3, $64-77$.

Becker, G. (1974). A theory of social interactions. Journal of Political Economy 82(06), 1063-1093.

Blanchflower, D. and A. Oswald (2004). Well-being over time in Britain and the USA. Journal of Public Economics 88(7), 1359-1386.

Borraz, F., S. Pozo, and M. Rossi (2010). And what about the family back home? International migration and happiness in Cuenca, Ecuador. Journal of Business Strategies 27(1).

Boyce, C. and A. Wood (2011). Personality and the marginal utility of income: Personality interacts with increases in household income to determine life satisfaction. Journal of Economic Behavior \& Organization 78(1-2), 183-191.

Brown, R. and E. Jimenez (2011). Subjectively-assessed welfare and international remittances: Evidence from Tonga. Journal of Development Studies 47(6), 829845.

Clark, A. (2003). Unemployment as a social norm: Psychological evidence from panel data. Journal of Labor Economics 21 (2), 323-351.

Clark, A., P. Frijters, and M. Shields (2008). Relative income, happiness, and utility: An explanation for the Easterlin paradox and other puzzles. Journal of Economic Literature 46(1), 95-144.

Clark, A. and A. Oswald (1994). Unhappiness and unemployment. The Economic Journal 104(424), 648-659. 
Clark, A. and A. Oswald (2002). A simple statistical method for measuring how life events affect happiness. International Journal of Epidemiology 31(6), 1139-1144.

Coate, S. and M. Ravallion (1993). Reciprocity without commitment: Characterization and performance of informal insurance arrangements. Journal of Development Economics 40(1), 1-24.

Cox, D. and M. Fafchamps (2007). Handbook of Development Economics - Chapter 58: Extended family and kinship networks: economic insights and evolutionary directions, Volume 4. Elsevier.

Cox, D., B. Hansen, and E. Jimenez (2004). How responsive are private transfers to income? Evidence from a laissez-faire economy. Journal of Public Economics 88(9), 2193-2219.

Diener, E., E. Suh, R. Lucas, and H. Smith (1999). Subjective well-being: Three decades of progress. Psychological Bulletin 125(2), 276.

Dolan, P., T. Peasgood, and M. White (2008). Do we really know what makes us happy? A review of the economic literature on the factors associated with subjective well-being. Journal of Economic Psychology 29(1), 94-122.

Dunn, E., L. Aknin, and M. Norton (2008). Spending money on others promotes happiness. Science 319(5870), 1687-1688.

Easterlin, R. (1995). Will raising the incomes of all increase the happiness of all? Journal of Economic Behavior \& Organization 27(1), 35-47.

Feng, S. and N. Heerink (2008). Are farm households' land renting and migration decisions inter-related in rural China? NJAS-Wageningen Journal of Life Sciences 55(4), 345-362.

Ferrer-i-Carbonell, A. and P. Frijters (2004). How important is methodology for the estimates of the determinants of happiness? The Economic Journal 114(497), 641-659.

Ferrer-i-Carbonell, A. and B. Van Praag (2003). Income satisfaction inequality and its causes. Journal of Economic Inequality 1(2), 107-127.

Frey, B. and A. Stutzer (2002). What can economists learn from happiness research? Journal of Economic literature 40(2), 402-435.

Fuentes, N. and M. Rojas (2001). Economic theory and subjective well-being: Mexico. Social Indicators Research 53(3), 289-314. 
Glenn, N. and C. Weaver (1978). A multivariate, multisurvey study of marital happiness. Journal of Marriage and the Family 40(2), 269-282.

Gong, X., S. Kong, S. Li, and X. Meng (2008). Rural-urban migrants: A driving force for growth. China's Dilemma: Economic Growth, the Environment and Climate Change, 110-152.

Gubert, F. (2002). Do migrants insure those who stay behind? Evidence from the Kayes area (Western Mali). Oxford Development Studies 30(3), 267-287.

Helliwell, J. (2003). How's life? Combining individual and national variables to explain subjective well-being. Economic Modelling 20(2), 331-360.

Hoddinott, J. (1994). A model of migration and remittances applied to Western Kenya. Oxford Economic Papers, 459-476.

Kahneman, D. and R. Sugden (2005). Experienced utility as a standard of policy evaluation. Environmental and Resource Economics 32(1), 161-181.

Kimball, M. (1988). Farmers' cooperatives as behavior toward risk. The American Economic Review 78(1), 224-232.

Kong, T. S. (2010). Rural-urban migration in China: Survey design and implementation. In X. Meng and C. Manning (Eds.), The Great Migration: Rural-Urban Migration in China and Indonesia, pp. 135-150. Edward Elgar Publishing.

Konow, J. (2010). Mixed feelings: Theories of and evidence on giving. Journal of Public Economics 94(3-4), 279-297.

Kotlikoff, L. and A. Spivak (1981). The family as an incomplete annuities market. The Journal of Political Economy 89(2), 372-391.

Lucas, R. and O. Stark (1985). Motivations to remit: Evidence from Botswana. The Journal of Political Economy 93(5), 901-918.

Ma, Z. (2001). Urban labour-force experience as a determinant of rural occupation change: Evidence from recent urban-rural return migration in China. Environment and Planning A 33(2), 237-256.

Murphy, R. (2002). How Migrant Labor is Changing Rural China. Cambridge University Press.

NBS China (2010). China Statistical Yearbook 2010. National Bureau of Statistics of China: Beijing, China.

Piracha, M. and A. Saraogi (2011). Motivations for remittances: Evidence from Moldova. IZA Discussion Papers $546 \%$. 
Rapoport, H. and F. Docquier (2006). The economics of migrants' remittances. Handbook on the Economics of Giving, Reciprocity and Altruism (2), 1135-1198.

Secondi, G. (1997). Private monetary transfers in rural China: Are families altruistic? The Journal of Development Studies 33(4), 487-511.

Snyder, S. and W. Chern (2008). The impact of remittance income on rural households in China. China Agricultural Economic Review 1(1), 38-57.

Stark, O. and D. Levhari (1982). On migration and risk in LDCs. Economic Development and Cultural Change 31(1), 191-196.

Tsai, M. and D. Dzorgbo (2012). Familial reciprocity and subjective well-being in Ghana. Journal of Marriage and Family 74(1), 215-228.

Vanwey, L. (2004). Altruistic and contractual remittances between male and female migrants and households in rural Thailand. Demography 41(4), 739-756.

Winkelmann, L. and R. Winkelmann (1998). Why are the unemployed so unhappy? Evidence from panel data. Economica 65(257), 1-15.

Yue, X. and S. Ng (1999). Filial obligations and expectations in china: Current views from young and old people in beijing. Asian Journal of Social Psychology 2(2), $215-226$. 


\section{Appendix}

Table A1: Summary statistics

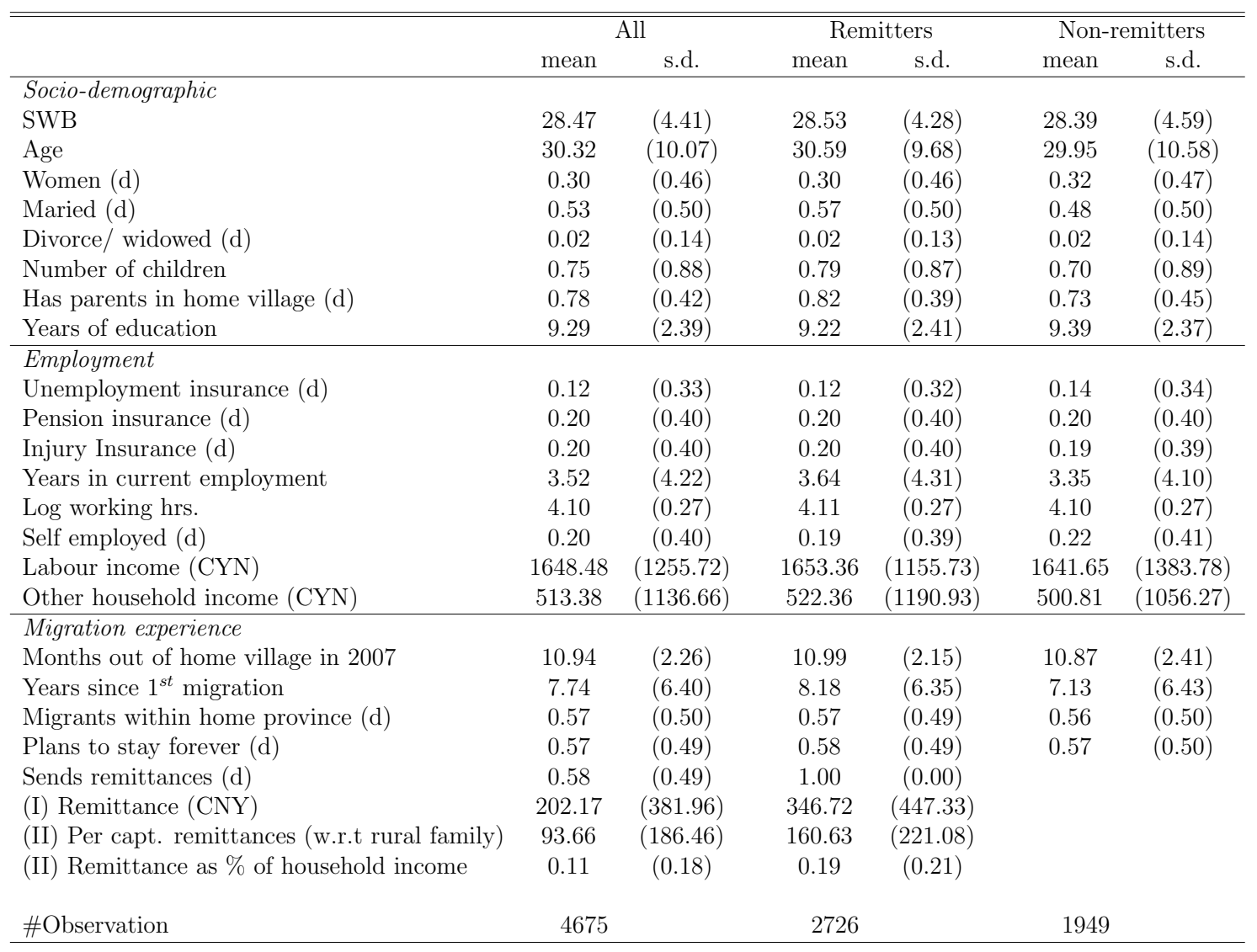

Source: RUMiC 2008. SWB refers to the GHQ-12 index described in the text, and ranges from 0 (lowest value) to 36 (highest value). (I) Remittances are constructed using information on the amount of money and commodities remitted back to the home village. (II) Per capita remittances are calculated by dividing the total amount of remittances by the number of members of the migrants' family in the home village using the modified OECD equivalence scale: Per capita remittances $=\frac{\text { Remittances }(1000 C Y N)}{1+0.5 *(\# \text { adults })+0.3 *(\# \text { children })}$. Note we only observe spouse, children, and parents and parents in law of the migrants. (III) Remittances as \% of household income is constructed by dividing the total amount of remittances by the total income of the migrant's household. 
Table A2: Benchmark regressions

\begin{tabular}{|c|c|c|c|c|}
\hline \multirow[t]{2}{*}{ Depende variable: } & \multicolumn{2}{|c|}{ SWB } & \multicolumn{2}{|c|}{ Remittances (CYN) } \\
\hline & $\begin{array}{l}\text { Not controlling } \\
\text { remittances }\end{array}$ & $\begin{array}{l}\text { Controlling } \\
\text { remittances }\end{array}$ & All & Only remitters \\
\hline Remittance (1000 CNY) & & $\begin{array}{l}0.389 \text { *** } \\
(0.135)\end{array}$ & & \\
\hline Age & $\begin{array}{l}-0.001 \\
(0.051)\end{array}$ & $\begin{array}{l}-0.001 \\
-0.051\end{array}$ & $\begin{array}{c}9.375 \\
(7.176)\end{array}$ & $\begin{array}{l}-2.288 \\
(5.391)\end{array}$ \\
\hline Age sq. & $\begin{array}{c}0.004 \\
(0.069)\end{array}$ & $\begin{array}{c}0.005 \\
(0.069)\end{array}$ & $\begin{array}{l}-16.391 * \\
(9.657)\end{array}$ & $\begin{array}{c}1.664 \\
(7.127)\end{array}$ \\
\hline Women (d) & $\begin{array}{l}-0.514 \text { *** } \\
(0.195)\end{array}$ & $\begin{array}{l}-0.506^{* * *} \\
(0.195)\end{array}$ & $\begin{array}{l}-29.455 \\
(27.290)\end{array}$ & $\begin{array}{l}-21.827 \\
(21.759)\end{array}$ \\
\hline Good health (d) & ref. & ref. & ref. & ref. \\
\hline Average health (d) & $\begin{array}{l}-1.786 * * * \\
(0.132)\end{array}$ & $\begin{array}{l}-1.790 * * * \\
(0.132)\end{array}$ & $\begin{array}{c}5.450 \\
(18.915)\end{array}$ & $\begin{array}{c}7.897 \\
(17.673)\end{array}$ \\
\hline Bad health (d) & $\begin{array}{l}-3.275 \text { *** } \\
(0.199)\end{array}$ & $\begin{array}{l}-3.287 \text { *** } \\
(0.199)\end{array}$ & $\begin{array}{l}54.118 \text { ** } \\
(25.908)\end{array}$ & $\begin{array}{c}22.137 \\
(24.889)\end{array}$ \\
\hline Married (d) & $\begin{array}{l}0.626^{* *} \\
(0.278)\end{array}$ & $\begin{array}{l}0.613 \text { ** } \\
(0.278)\end{array}$ & $\begin{array}{c}50.719 \\
(39.277)\end{array}$ & $\begin{array}{c}44.307 \\
(32.409)\end{array}$ \\
\hline Divorced/Widowed (d) & $\begin{array}{l}-1.228 * * \\
(0.572)\end{array}$ & $-1.215^{* *}$ & $\begin{array}{l}-79.991 \\
(71.604)\end{array}$ & $\begin{array}{c}3.822 \\
(54.927)\end{array}$ \\
\hline Has no children age $\leq 16$ (d) & ref. & ref. & ref. & ref. \\
\hline Has a child age $\leq 16$ (d) & $\begin{array}{l}-0.134 \\
(0.249)\end{array}$ & $\begin{array}{l}-0.153 \\
(0.248)\end{array}$ & $\begin{array}{l}78.053 \quad * * \\
(35.152)\end{array}$ & $\begin{array}{l}51.662 \\
(33.162)\end{array}$ \\
\hline $\begin{array}{l}\text { Has } 2 \text { or more children age } \leq 16(\mathrm{~d}) \\
\text { Has no adult children (d) }\end{array}$ & $\begin{array}{l}0.209 \\
(0.320) \\
\text { ref. }\end{array}$ & $\begin{array}{l}0.166 \\
(0.320) \\
\text { ref. }\end{array}$ & $\begin{array}{l}123.533 * * * \\
(44.342) \\
\quad \text { ref. }\end{array}$ & $\begin{array}{l}146.327 * * * \\
(49.187) \\
\quad \text { ref. }\end{array}$ \\
\hline Has an adult children (d) & $\begin{array}{l}-0.075 \\
(0.307)\end{array}$ & $\begin{array}{l}-0.087 \\
(0.307)\end{array}$ & $\begin{array}{c}14.179 \\
(42.376)\end{array}$ & $\begin{array}{c}71.831 \\
(42.468)\end{array}$ \\
\hline Has 2 or more adult children (d) & $\begin{array}{c}0.428 \\
(0.402)\end{array}$ & $\begin{array}{c}0.401 \\
(0.402)\end{array}$ & $\begin{array}{l}95.784 * \\
(57.483)\end{array}$ & $\begin{array}{c}72.977 \\
(54.383)\end{array}$ \\
\hline Years since $1^{\text {st }}$ migration & $\begin{array}{l}-0.058 * \\
(0.034)\end{array}$ & $\begin{array}{l}-0.061 * \\
(0.034)\end{array}$ & $\begin{array}{l}18.828 * * * \\
(4.692)\end{array}$ & $\begin{array}{c}6.829 \\
(5.302)\end{array}$ \\
\hline Years since $1^{\text {st }}$ migration sq. & $\begin{array}{l}0.002 * \\
(0.001)\end{array}$ & $\begin{array}{l}0.002 * \\
(0.001)\end{array}$ & $\begin{array}{l}-0.552 \quad * * * \\
(0.171)\end{array}$ & $\begin{array}{l}-0.197 \\
(0.222)\end{array}$ \\
\hline Migrated within home province (d) & $\begin{array}{c}0.188 \\
(0.218)\end{array}$ & $\begin{array}{c}0.195 \\
(0.217)\end{array}$ & $\begin{array}{l}-17.453 \\
(32.355)\end{array}$ & $\begin{array}{l}-12.383 \\
(43.321)\end{array}$ \\
\hline Years of education & $\begin{array}{l}0.165 \text { *** } \\
(0.030)\end{array}$ & $\begin{array}{l}0.165 * * * \\
(0.030)\end{array}$ & $\begin{array}{l}-0.017 \\
(4.031)\end{array}$ & $\begin{array}{c}2.549 \\
(3.552)\end{array}$ \\
\hline Log working hrs. & $\begin{array}{l}-1.084 \text { *** } \\
(0.281)\end{array}$ & $\begin{array}{l}-1.086 \text { *** } \\
(0.281)\end{array}$ & $\begin{array}{c}28.337 \\
(37.623)\end{array}$ & $\begin{array}{c}20.747 \\
(39.941)\end{array}$ \\
\hline Years in current employment & $\begin{array}{c}0.008 \\
(0.017)\end{array}$ & $\begin{array}{c}0.008 \\
(0.017)\end{array}$ & $\begin{array}{c}1.244 \\
(2.378)\end{array}$ & $\begin{array}{c}0.140 \\
(2.878)\end{array}$ \\
\hline Long employment contract (d) & $\begin{array}{l}0.434 \text { *** } \\
(0.145)\end{array}$ & $\begin{array}{l}0.4344^{* * *} \\
(0.145)\end{array}$ & $\begin{array}{c}4.011 \\
(20.515)\end{array}$ & $\begin{array}{c}0.955 \\
(18.291)\end{array}$ \\
\hline Self-employed (d) & $\begin{array}{l}0.484 \text { ** } \\
(0.206)\end{array}$ & $\begin{array}{l}0.534 \text { *** } \\
(0.206)\end{array}$ & $\begin{array}{l}-198.571 \text { *** } \\
(28.210)\end{array}$ & $\begin{array}{l}-180.030 \text { *** } \\
(28.871)\end{array}$ \\
\hline Unemployment insurance (d) & $\begin{array}{l}0.570 \text { ** } \\
(0.248)\end{array}$ & $\begin{array}{l}0.586 \text { ** } \\
(0.249)\end{array}$ & $\begin{array}{l}-87.599 \text { ** } \\
(38.392)\end{array}$ & $\begin{array}{l}-25.525 \\
(33.172)\end{array}$ \\
\hline Pension insurance (d) & $\begin{array}{l}-0.602 \text { *** } \\
(0.223)\end{array}$ & $\begin{array}{l}-0.583 \text { *** } \\
(0.223)\end{array}$ & $\begin{array}{l}-66.460 \\
(33.476)\end{array}$ & $\begin{array}{l}-64.401 \text { ** } \\
(31.769)\end{array}$ \\
\hline Injury insurance (d) & $\begin{array}{l}0.728 \text { *** } \\
(0.218)\end{array}$ & $\begin{array}{l}0.701 \text { *** } \\
(0.218)\end{array}$ & $\begin{array}{l}109.047 \text { *** } \\
(32.405)\end{array}$ & $\begin{array}{l}62.717 \text { ** } \\
(30.986)\end{array}$ \\
\hline labour income (1000 CYN) & $\begin{array}{l}0.140 \text { *** } \\
(0.047)\end{array}$ & $\begin{array}{l}0.115 * * \\
(0.047)\end{array}$ & $\begin{array}{l}80.935 \\
(7.305)\end{array}$ & $\begin{array}{l}120.296 \text { *** } \\
(25.021)\end{array}$ \\
\hline Other household income (1000 CYN) & $\begin{array}{l}0.102 * \\
(0.054)\end{array}$ & $\begin{array}{l}0.104 * * \\
(0.053)\end{array}$ & $\begin{array}{l}-7.100 \\
(7.898)\end{array}$ & $\begin{array}{l}-2.624 \\
(8.543)\end{array}$ \\
\hline Constant & $\begin{array}{l}31.923 \text { *** } \\
(2.779)\end{array}$ & $\begin{array}{l}31.979 \text { *** } \\
(2.776)\end{array}$ & $\begin{array}{l}-405.169 \\
(387.033)\end{array}$ & $\begin{array}{l}-461.007 \\
(368.799)\end{array}$ \\
\hline Sigma constant & & & $\begin{array}{l}525.571 \text { *** } \\
(7.562)\end{array}$ & \\
\hline$R^{2}$ & 0.172 & 0.173 & & 0.168 \\
\hline \#Obs. & 4675 & 4675 & 4675 & 2726 \\
\hline
\end{tabular}

Source: RUMiC 2008. */**/*** indicate significance at the $10 \% / 5 \% / 1 \%$ level. Third column is a censured tobit, all others are OLS regressions. (d) refers to dummy variables. All regressions include additional controls regarding rural village characteristics not reported due to limited space. 